\title{
Six Key Traits of Fungi: Their Evolutionary Origins and Genetic Bases
}

\author{
LÁSZLÓ G. NAGY, ${ }^{1}$ RENÁTA TÓTH, ${ }^{2}$ ENIKÖ KISS, ${ }^{1}$ JASON SLOT, ${ }^{3}$ \\ ATTILA GÁCSER, ${ }^{2}$ and GÁBOR M. KOVÁCS ${ }^{4,5}$
}

${ }^{1}$ Synthetic and Systems Biology Unit, Institute of Biochemistry, HAS, Szeged, Hungary; ${ }^{2}$ Department of Microbiology, University of Szeged, Szeged, Hungary; ${ }^{3}$ Department of Plant Pathology, Ohio State University, Columbus, OH 43210; ${ }^{4}$ Department of Plant Anatomy, Institute of Biology, Eötvös Loránd University, Budapest, Hungary; ${ }^{5}$ Plant Protection Institute, Center for Agricultural Research, Hungarian Academy of Sciences, Budapest, Hungary

\begin{abstract}
The fungal lineage is one of the three large eukaryotic lineages that dominate terrestrial ecosystems. They share a common ancestor with animals in the eukaryotic supergroup Opisthokonta and have a deeper common ancestry with plants, yet several phenotypes, such as morphological, physiological, or nutritional traits, make them unique among all living organisms. This article provides an overview of some of the most important fungal traits, how they evolve, and what major genes and gene families contribute to their development. The traits highlighted here represent just a sample of the characteristics that have evolved in fungi, including polarized multicellular growth, fruiting body development, dimorphism, secondary metabolism, wood decay, and mycorrhizae. However, a great number of other important traits also underlie the evolution of the taxonomically and phenotypically hyperdiverse fungal kingdom, which could fill up a volume on its own. After reviewing the evolution of these six well-studied traits in fungi, we discuss how the recurrent evolution of phenotypic similarity, that is, convergent evolution in the broad sense, has shaped their phylogenetic distribution in extant species.
\end{abstract}

\section{INTRODUCTION}

The fungal lineage is one of the three large eukaryotic lineages that dominate terrestrial ecosystems. They share a common ancestor with animals in the eukaryotic supergroup Opisthokonta and have a deeper common ancestry with plants, yet several phenotypes such as morphological, physiological, or nutritional traits make them unique among all living organisms. This article provides an overview of some of the most important fungal traits, how they evolve, and what major genes and gene families contribute to their development. The traits highlighted here represent just a sample of the characteristics that have evolved in fungi, including polarized multicellular growth, fruiting body development, dimorphism, secondary metabolism, wood decay, and mycorrhizae. However, a great deal of other important traits also underlie the evolution of the taxonomically and phenotypically hyperdiverse fungal kingdom, which could fill up a volume on its own. After reviewing the evolution of these six well-studied traits in fungi, we discuss how the recurrent evolution of phenotypic similarity, that is, convergent evolution in the broad sense, has shaped their phylogenetic distribution in extant species.

Received: 29 November 2016, Accepted: 31 May 2017,

Published: 18 August 2017

Editors: Joseph Heitman, Department of Molecular Genetics and Microbiology, Duke University Medical Center, Durham, NC 27710; Neil A. R. Gow, School of Medical Sciences, University of Aberdeen, Fosterhill, Aberdeen, AB25 2ZD, United Kingdom

Citation: Nagy LG, Tóth R, Kiss E, Slot J, Gácser A, Kovács GM. 2017. Six key traits of fungi: their evolutionary origins and genetic bases. Microbiol Spectrum 5(4):FUNK-0036-2016. doi:10.1128 /microbiolspec. FUNK-0036-2016.

Correspondence: László Nagy, cortinarius2000@gmail.com (c) 2017 American Society for Microbiology. All rights reserved. 


\section{THE EVOLUTION AND DE-EVOLUTION OF MULTICELLULARITY}

Multicellular life dominates most ecosystems on Earth, and its evolution is considered to be one of the major transitions in the history of life. Multicellularity confers several competitive advantages. Among others, it allows the division of labor between cells, increased size and complexity, a longer life span, or an advantage in avoiding predation. It has been estimated that multicellularity evolved in some form 25 to 30 times both in the prokaryotes and the eukaryotes, but most of those lineages are simple aggregates or colonies of cells that show little phenotypic or functional differentiation. Fungi represent one of the few lineages that have achieved higher levels of multicellular complexity. Like animals and plants, fungi evolved integrated multicellular structures that enable them to adapt to diverse ecological niches. However, unlike animals and plants, fungi evolved complex multicellularity through filamentous intermediate stages. Fungal filaments (hyphae), unlike filamentous forms in other lineages, develop by polarized apical growth, and individual cells are divided from the elongating hypha by developing cross-walls (septa), a unique solution for filamentous growth seen mostly in higher fungi (1). Hyphae have been hypothesized to have emerged through gradual elongation of substrateanchoring rhizoids of ancestral unicellular fungi such as chytrids (2).

Similar, apically growing hyphae have evolved in the Oomycetes (Stramenopila), but oomycete hyphae are not septate, allowing the transport of compounds and organelles along the hyphae. Such aseptate hyphae are a multinucleate, coenocytic architecture, similar to hyphae of early-diverging fungal groups (e.g., Mucoromycota). Within fungi, hyphae evolved convergently in multiple groups (Fig. 1A,B), one of them comprising most of the well-known filamentous fungi. Other hyphal groups include the Monoblepharidomycetes, an early-diverging lineage of aquatic fungi in which several species have switched to filamentous growth (프), and certain chytridlike fungi.

Fungal mycelia-intricate branching networks of hyphae-are adapted to efficiently explore the available space in the substrate. Foraging for nutrients may have driven the emergence of multicellularity in fungi, although transition to terrestrial habitats and exploitation of prokaryotic biofilms have also been proposed as the necessary selection pressures for their emergence (4). The first multicellular hyphae evolved in the common ancestor of the Zoopagomycota, Mucoromycota, and the Dikarya and were probably similar to those of extant
Mucoromycota mucoralean fungi such as the bread mold Rhizopus stolonifer. Early filamentous species have relatively simple, little-differentiated mycelia of tube-like cells that are not (or are minimally) compartmentalized by septa. More derived fungi evolved various solutions to block the free diffusion of materials in hyphae, which would also minimize the risk of the free passage of external invaders (5). Specialized structures around septa, including Woronin bodies and the dolipore septum among others, serve to regulate transport between cells in the hyphae of Asco- and Basidiomycota, respectively, although exceptions to this rule exist. Neolecta vitellina, a basal ascomycete (Taphrinomycotina), produces crystalline bodies analogous to Woronin bodies but which are of vacuolar origin and only loosely bound to the membrane (6). Although structurally different, all three solutions provide the means to finely coordinate the transport of goods and to block the diffusion of organelles from one cell to the other.

\section{Polarized Growth and the Underlying Cellular Components}

Polarized hyphal growth of fungi is a unique innovation in the history of life, with similar solutions seen only in a few other groups such as Oomycota and the pollen tubes of seed plants and axons of some neurons. The orchestration of hyphal growth involves several cellular pathways and entailed the evolution of several novel traits, including the establishment of polarity, apical extension, the coordinated transport of material to the sites of active growth, the establishment of branching, and septation patterns. In hyphae, growth occurs in the apical zone, coincident with a strong gradient of cell wall material deposition toward the tip. Apical growth is achieved by the expansion of the hyphal tip, which is predominantly driven by turgor pressure within the cell that, in turn, is regulated by the osmotic mitogen-activated protein kinase cascade (7). Cell wall materials are transported by secretory vesicles to the growing tip along cytoskeletal structures (7). One of the core signal transduction pathways connected to polarity establishment is the Ras/Rho GTPase pathway described in Saccharomyces cerevisiae, which is also conserved in filamentous fungi. This pathway is responsible for polarity establishment and maintenance by the formation of a stable polarity axis that specifies the site of germ tube emergence. This positional information is generated by the recruitment of cell polarity proteins (Bud4, Ax12, swoC in Aspergillus nidulans) at the site of polarized growth $(\underline{8})$ and then is transduced via regulatory Rho GTPases (RacA A. nidulans, CDC42 
A
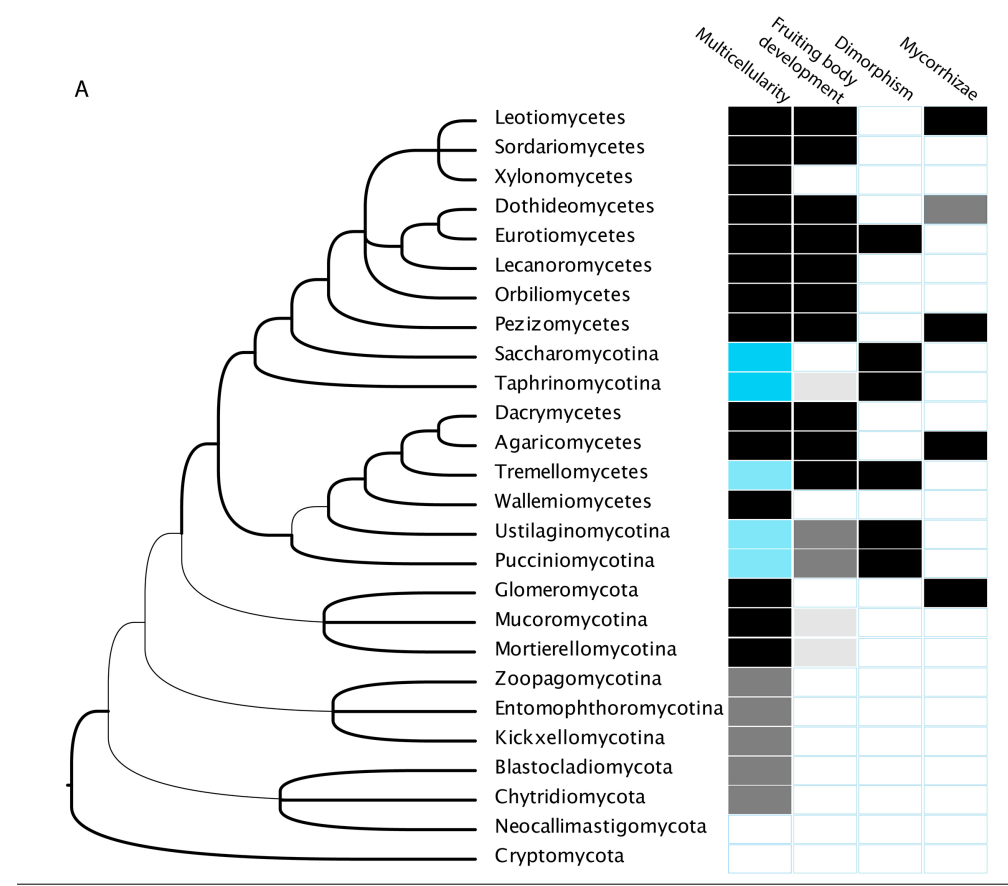
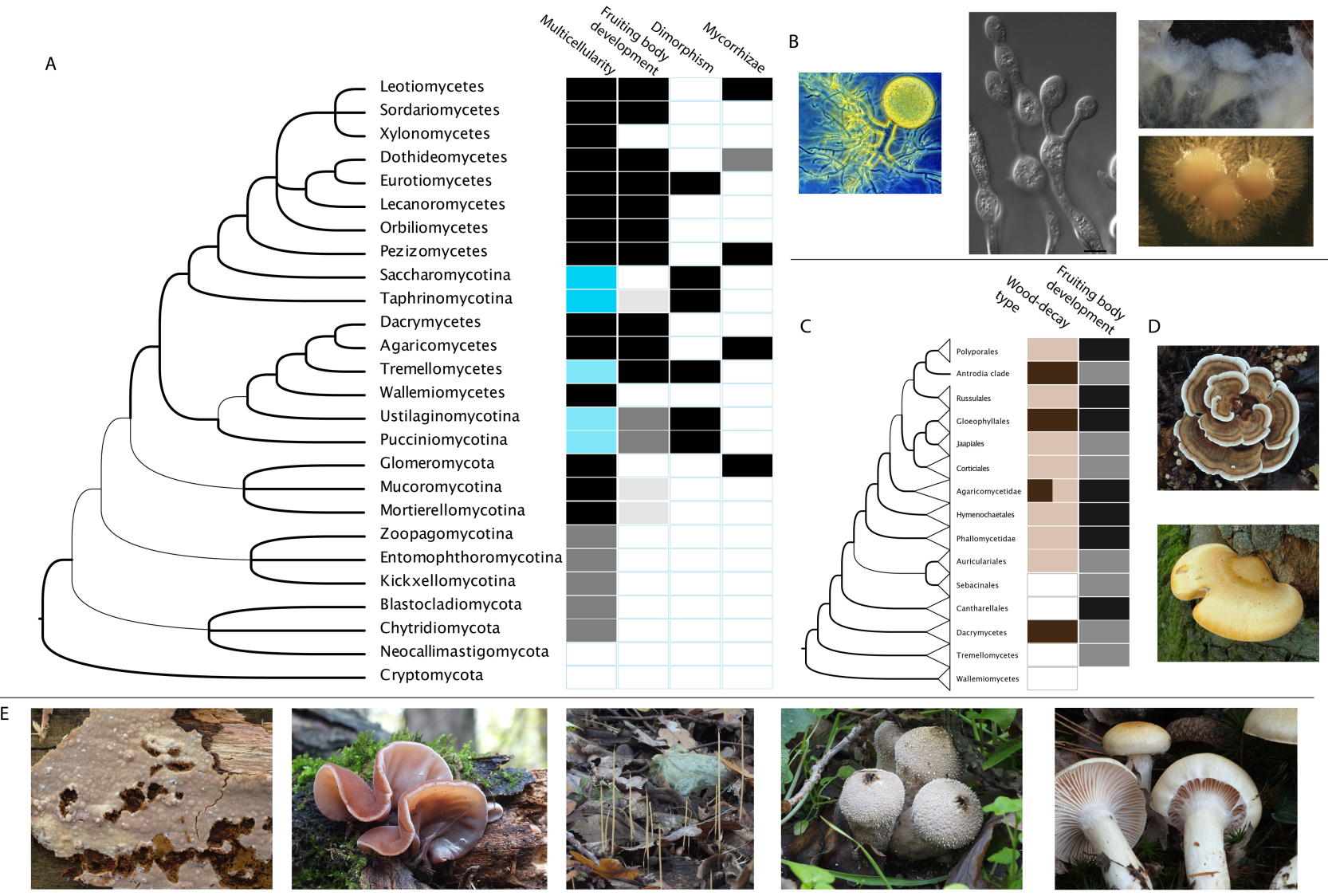

FIGURE 1 Overview of the phylogenetic distribution of the traits presented in this article. (A) Phylogeny of the major fungal groups and the phylogenetic distribution of the traits discussed in this article. Tree modified and redrawn from MycoCosm (http://genome.jgi.doe.gov/programs/fungi/index.jsf). Thick branches denote well-known relationships, while thin branches mark uncertainties in our understanding of fungal relationships. Presence or absence of a given trait is highlighted by black or white shading, respectively. Gray shading denotes rare or not fully developed states of the given trait, while blue denotes the secondary partial loss of multicellular growth in yeasts. (B) The evolution of hyphae from unicellular ancestors (left, Spizellomyces punctatus; photo courtesy of Don Barr, http://www.bsu.edu/classes/ruch/msa/barr/4-15.jpg). Hyphae evolved in several groups, including the Monoblepharidomycetes (middle, Monoblepharella sp.; [from reference 3]) and the crown fungi (top right, Psathyrella spadiceogrisea mycelium growing on sawdust). Also shown are hyphal and yeast-like colonies of the dimorphic fungus Aureobasidium pullulans (bottom right). (C) Detailed view of the major orders, their woodrotting characteristics, and the distribution of agaricoid fruiting body morphologies of the Agaricomycetes. Brown and beige represent brown and white rot lineages, respectively, whereas empty rectangles denote groups that do not degrade wood (Wallemiomycetes, Tremellomycetes) or cause an uncharacterized type of wood decay or mycorrhiza (Sebacinales and Cantharellales). (D) Examples of typical white (Trametes versicolor, top) and brown (Piptoporus quercinus, bottom) rot Basidiomycota. (E) Examples of the diversity of fruiting body morphologies in the Agaricomycetes, including from left to right, resupinate (Cylindrobasidium evolvens); auricularioid, jelly fungi (Auricularia auricula-judae); club and coral fungi (Typhula phacorrhiza); puffballs (Lycoperdon perlatum); and agaricoid morphologies (Hygrophorus sp). Photos: L. Nagy unless stated otherwise. 
S. cerevisiae) toward the morphogenetic machinery, which is the main organizer of tipward secretion, cell wall expansion, and tip growth $(\underline{1}, \underline{9})$.

The key contributor to the hyphal morphogenetic machinery is the Spitzenkörper (10). It is hypothesized to serve as a vesicular distributor between the microtubular vesicular transport system and the actin patches accumulated at the apex, and therefore it is responsible for the growth directionality of hyphae. These vesicles transport structural and landmark proteins, proteins that facilitate membrane docking and fusion, different enzymes (chitin synthase), and $\mathrm{Ca}^{2+}$, components that are essential for hypha elongation. The microtubule network connected to the Spitzenkörper has an indirect role in polarity maintenance and hyphal growth and is responsible for the long-range vesicular transport to the apex (11).

In addition to the microtubular network, the actin cytoskeleton is also connected to the Spitzenkörper. It has a crucial role in taking vesicles delivered to the apex via myosin-based transport and guiding them to polarization/secretion sites serving as a bridge between the Spitzenkörper and the extension site of the hyphal apex. The actin cytoskeleton is regulated by different polarity-establishing and -maintaining factors: the polarisome and the Arp $2 / 3$ protein complex. Both of these complexes have a role in actin polarization; the polarisome is responsible for the organization of the actin cytoskeleton to the expansion site by formin-dependent actin polarization (SepA and MesA in A. nidulans; Spa2, Bud6, and Bni1 in Neurospora crassa). The Arp2/3 complex in turn controls the building of cortical actin patches at the apex which have a crucial role in endocytosis (12).

Precise coordination of vesicle delivery to the expansion site is essential for polarized growth. The key regulators of this process are the Coatomer complex that mediates vesicle formation (SEC proteins, Sec21 in N. crassa), the exocyst complex (SEC proteins, Exo-70, and Exo-84 in S. cerevisiae; RabA/B in A. nidulans), which is a conserved multiprotein complex with a role in vesicle targeting and vesicle distribution from the Spitzenkörper, and finally, the SNARE complex (nsyn1 and nsyn 2 SNAREs in N. crassa), which facilitates vesicle fusion with specific membrane types (13).

The rapid rate of hyphal extension requires a large amount of cell wall components deposited at the extension site. According to the steady state theory of hyphal wall growth, the plastic wall material (chitin, 1-3beta glucan) has to be synthesized and delivered continuously to the apex to elongate the hypha. After deposition, cross-linking mechanisms rigidify the proto cell wall material, and only the hyphal apex is plastic enough to grow continuously. This process is coordinated by various cell wall-synthesizing enzymes: glucanases and different types of chitin synthases (chsB/D/E in A. nidulans and chs1 in N. crassa).

Along with the elongated morphology, septation and branching patterns are also characteristic morphological features of filamentous fungi. Mitotic signals and cortical markers are the inducers of septation, and the morphogenetic machinery behind this process is composed of actin cytoskeleton, septins (aspA-E in A. nidulans), and formins (sepA/D/G/H) (14). Septation and branching are two morphogenetically connected events. In septum-forming fungi, the branching event occurs just after septation and starts with the generation of a new polarity axis, followed by the recruitment of the morphogenetic machinery to induce branch emergence. In N. crassa, the characteristic pod proteins (pod4/5/8) are required for branch formation, but interestingly, they have no obvious role in the morphogenesis of primary hyphae ( $\underline{8})$.

\section{The De-Evolution of the Multicellular Life Stage}

Many fungal groups seem to have secondarily lost multicellularity. These are collectively known as yeasts, and they are some of the best-studied and economically most important eukaryotic organisms such as S. cerevisiae and Schizosaccharomyces pombe. The term "yeast" covers a polyphyletic assemblage of phenotypically similar fungi, many of which are only distantly related to each other. It usually refers to species that are unicellular through most of their life cycle and divide through budding or fission. Such species evolved in many major groups, including the Asco- and Basidiomycota and certain Mucoromycota, and can be found in large clades such as the Saccharomycotina or derived as smaller groups within diverse clades of filamentous fungi. The most widely known ascomycete yeasts include the genera Saccharomyces, Candida, Pichia, and Yarrowia in the Saccharomycotina subphylum; Schizosaccharomyces in the Taphrinomycotina; as well as several species in phylogenetically dispersed clades (for details see reference 15). Basidiomycete yeasts occur in two large clades: the Pucciniomycotina (e.g., Rhodotorula and Sporobolomyces) and the Tremellomycetes (e.g., Cryptococcus and Xanthophyllomyces [formerly Phaffia]). Yeasts evolved from multicellular filamentous ancestors; the independent origin of similar cellular morphologies in diverse groups is a fascinating example of convergent 
evolution and probably reflects adaptation to similar niches. With their unicellular habit, morphology, and limited dispersal abilities, yeasts are adapted to liquid environments and to the absorption of simple sugars, in contrast to filamentous fungi, which can forage for nutrients over larger distances and drier environments. In nature, yeasts are mostly found in aquatic habitats or moist, sugar-rich environments such as fruits, floral nectars, and other plant exudates or as members of the intestinal microbial flora of animals.

Most people view yeasts as unicellular eukaryotes that have greatly contributed to our understanding of several conserved cellular processes of eukaryotes. Because of this, yeasts are often viewed as the de-evolution of multicellularity in fungi. However, most yeasts, even those that grow as single-celled organisms during most of their life cycle, are able to switch to filamentous growth as a response to changing environmental conditions (for details see the section on dimorphic fungi). Some of them produce only pseudohyphae, elongate to cylindrical cells that are more similar to elongated yeast cells than to real hyphae. However, many species can grow typical hyphae too. Thus, most yeasts are not unicellular in the traditional sense (16).

The mostly unicellular Saccharomycotina group contains Eremothecium gossypii (Ashbya gossypii), a species that produces elongate, unseptate hypha-like cells that resemble the true hyphae of filamentous fungi. The phylogenetic position of E. gossypii within yeasts suggests that its filamentous cells represent a step toward the re-evolution of hyphal growth, although molecular studies suggest that the filaments of E. gossypii are more similar to elongated yeast cells than to true hyphae (9).

Yeasts have small, streamlined genomes compared to filamentous fungi, containing 6,000 to 8,000 genes, on average. Their evolution from filamentous ancestors represents a classic example of convergent evolution and has been marked by extensive gene losses, on average, 3,000 to 5,000 lost genes per lineage, which affected a wide array of genes related to complex polysaccharide metabolism such as genes coding for plant cell wall-degrading enzymes (PCWDEs), secondary metabolism, oxidoreductases, cyclophilins, or hydrophobins (17). Their highly streamlined genomes, however, contain many genes required for hyphal morphogenesis, suggesting a close relationship between multicellular hyphal growth and yeast divisions and/or pseudohyphal growth. Recent results suggest that the convergent evolution of yeast-like fungi is a result of parallel deployment of dormant developmental potentials, rather than the result of the independent evolution of similar genetic toolkits. Convergent diversification of conserved ( $\mathrm{Zn}-$ cluster) transcription factor families might have led to the potential for yeast-like growth to become dominant in the life cycle at the cost of partial or complete loss of hyphal growth (17). It has also been shown that the genes required for yeast-like growth, including chitin and glucan synthases, as well as chitinases and glucanases involved in separating mother and daughter cells, evolved early in fungi and are shared by mostboth filamentous and yeast-like-fungi, which raises the question of what function these genes are responsible for in nonyeast fungi. Because of the similarity between yeast budding and fission and conidium and arthrospore generation, it is tempting to speculate that the cradle for yeast-like growth could have been the morphogenetic machinery of asexual reproduction, although this needs to be tested.

\section{FUNGAL DIMORPHISM}

Dimorphic fungal species have the ability to reversibly switch between hyphal and yeast or yeast-like morphologies in response to different stimuli (Fig. 1B), particularly shifts in environmental conditions. Dimorphism is a frequent characteristic of pathogenic fungal species of plants, insects, and humans and other mammalian hosts, and it contributes to their capacity to cause tens of millions of infections annually worldwide. Generally, in dimorphic pathogens of insects and humans and other mammals, the yeast phase is considered to be more pathogenic because this form is able to spread throughout the body, resulting in systemic infection. The role of filamentous growth is also fundamental: besides promoting host tissue adhesion, this form also contributes to transmission to new hosts, maintains survival in the environment, and is required for mating and thus for genetic diversity.

In phytopathogenic fungi, the role of yeast forms in pathogenicity is species specific. Usually it is the mycelial phase that infects plant tissues. In both morphological states one can distinguish between yeast-phase-specific and hyphal-phase-specific gene expressions, while most of the housekeeping genes remain constitutively expressed regardless of the cell type. The expression of phase-specific genes depends on the morphotype and might be associated with virulence.

The six primary pathogens in the Ascomycota that are traditionally classified as dimorphic fungi and cause systemic disease in humans are Blastomyces dermatitidis (blastomycosis), Coccidioides immitis (coccidioidomycosis, or valley fever), Histoplasma capsulatum 
(histoplasmosis), Paracoccidioides brasiliensis (paracoccidioidomycosis), Sporothrix schenckii (sporotrichosis), and Penicillium marneffei (penicilliosis) (18).

\section{Molecular Mechanisms of Switching Between Yeast and Hyphal Stages}

A common mnemonic used for thermally dimorphic fungi is "mold in the cold, yeast (yeast-like) in the heat." In general, the majority of these species are environmental saprobes of the soil, water, etc. and grow as molds at 20 to $25^{\circ} \mathrm{C}$. Once the environmental milieu is disrupted and the conidia (e.g., spores) or hyphal fragments are inhaled by or inoculated into humans or other mammalian hosts, dimorphic transition from hyphal growth to yeast or spherule (Coccidioides spp.) occurs at $37^{\circ} \mathrm{C}(19, \underline{20})$.

Following uptake by alveolar macrophages, a large number of fungal transcripts appear that promote adaptation to the new restrictive environment (21). These transcripts induce hyphae to yeast dimorphic transition, cell wall rearrangement, sporulation, and the expression of other possible virulence-effecting genes that alter metabolic pathways. All are required for successful immune evasion, intracellular survival, and systemic dissemination (18). Dimorphic transition is mainly temperature dependent, although other nonthermal signals such as increased $\mathrm{CO}_{2}$ tension, oxidative stress, and mammalian hormones such as estradiol or L-DOPA could contribute (22-24).

Inside the host, the yeast-like phase is fundamental for successful invasion. During the transition, besides changes in cell size and shape, a large number of yeastphase- or spherule-phase-specific genes are activated, resulting in cell wall reassembly and alterations in certain signaling pathways $(\underline{18}, \underline{20})$. For example, $\beta$-glucans are one of the most relevant pathogen-associated molecular patterns in the fungal cell wall that are recognized quickly by the host immune cells and enhance efficient clearance $(\underline{25})$. However, in the yeast phase of certain dimorphic fungi, the amount of $\alpha$-glucan in the cell wall is elevated, which may conceal the immune recognizable $\beta$-glucans from the host $(\underline{26}, \underline{27})$.

Because pathogenicity of these fungi is possibly a consequence of adaptation to the host environment, most signaling pathways associated with virulence are suggested to be sensors of environmental stress. These pathways can include, for example, the protein kinase $\mathrm{C}$ cell wall integrity, the cyclic AMP protein kinase A (PKA), calcium-calcineurin, and other two-component pathways. The two main intracellular signaling pathways associated with morphology transition are the cyclic AMP-PKA and the mitogen-activated protein kinase (MAPK) cascade pathways (22). Detection of changes in the amount of the available carbon or nitrogen sources leads to elevated cyclic AMP levels intracellularly, which stimulates PKA. PKA then activates the transcription of factors needed for the dimorphic switch. MAPK cascades consist of several kinases responding to various environmental stimuli and induce a wide variety of response mechanisms. Such kinases include mainly serine, threonine, and tyrosine kinases but also kinases that phosphorylate histidine residues of proteins. A hybrid dimorphism-regulating histidine kinase (DRK1) in B. dermatitidis was identified and considered to be a global regulator of morphology switch (18). DRK1 is highly conserved among three dimorphic fungi species and plays a key role in sporulation, hyphae-to-yeast transition, cell wall integrity, and virulence.

Recent studies and observations cumulatively suggest that mammal-infecting dimorphic fungi have evolved several strategies to evade the host immune responses. Such strategies include masking their pathogenassociated danger signals, altering fungal signaling pathways, and promoting intracellular survival. An additional example is the oxidative stress-evading strategy of $H$. capsulatum and $P$. brasiliensis (28-30). Both species evolved their own nitric oxide reductase and several catalase enzymes to overcome the effect of reactive oxygen and nitrogen species produced by host cells.

\section{Dimorphism Is Widespread among Fungi}

Another mnemonic that refers to dimorphic fungal pathogens is "Body heat probably changes shape." This phrase allows the inclusion of certain Candida spp. in the group of dimorphic species because of the ability of switching morphology in the opposite direction, from yeast to filamentous growth (Fig. 1A). Of these species, Candida albicans is known as polymorphic because it is able to exist in yeast, hyphal, or pseudohyphal forms and is the primary species responsible for candidiasis of the oral mucosa, skin, and genitalia. Despite being a human commensal, C. albicans and other non-albicans Candida spp. are able to cause severe disease in immunosuppressed patients (31-34). Filamentous growth is required for host tissue adhesion and penetration. Although by definition, pseudohyphae are considered to be elongated blastospores, their contribution to tissue damage and penetration along with true hyphae has also been confirmed by numerous studies.

Commonly occurring Candida spp. that are able to exist in all three forms, in addition to C. albicans, 
include Candida dubliniensis and possibly Candida tropicalis, while species capable of switching between only yeast and pseudohypae are Candida parapsilosis, Candida guilliermondii, and Candida lusitaniae (35).

Other examples of ascomycetes reported to be dimorphic and frequently associated with pathogenic behavior are Exophiala dermatitidis (Chaetothyriomycetes), Lacazia loboi (Eurotiomycetes), and Aureobasidium pullulans (Dothideomycetes). All of these species are associated with subcutaneous infections. Besides ascomycetes, morphotype-associated pathogenicity is also observed among basidiomycetes that infect mammalian hosts. Although Cryptococcus neoformans is not considered to be a dimorphic fungus, this species has a unique property of forming "giant," or "titan," cells in the host. Further studies have also described morphotypeassociated pathogenicity among certain Zygomycota and dermatophyte species $(\underline{36}, \underline{37})$.

\section{Plant Pathogenic Dimorphic Fungi}

Dimorphic fungi are also common pathogens of important crops. In contrast to pathogenic fungi of mammals, phytopathogens are usually considered saprobic in the unicellular yeast phase but parasitic in the filamentous stage inside the plant. The role of the yeast form in pathogenicity is species specific and may contribute to dissemination (38). In the majority of cases, to penetrate the structural barrier of plant cells, hyphal growth is needed. Examples include Taphrina deformans, a common phytopathogen responsible for peach leaf curl, and Ustilago maydis, which is associated with corn smut disease. Once reaching the plant surface, both U. maydis and $T$. deformans switch from budding yeast to filamentous growth (21). The phenomenon is induced by mating in U. maydis, although not in T. deformans (39, 40). Ophiostoma ulmi and Ophiostoma novo-ulmi are the main causative species of Dutch elm disease. Additional factors that promote morphology change in Ophiostoma spp. include lipoxygenases, cyclooxygenases, nitrogen sources, and quorum sensing molecules (41). Filamentous forms of Ophiostoma spp. invade between the vascular structures, while blastospores disseminate in the xylem network of the infected elm trees.

Current scientific research is concerned about exploring the underlying conditions and exact altered signaling mechanisms that help dimorphic fungi to adapt to the host environment. Several mechanisms for yeasthyphal switches have already been revealed, although our full understanding of morphotype-associated pathogenicity and thus the origin of virulence is still incomplete.

\section{FRUITING BODIES}

Fruiting bodies are some of the most spectacular morphological structures of fungi. Compared to indeterminately growing vegetative mycelia, sexual fruiting bodies result from temporally and spatially integrated developmental programs. In this regard, they resemble multicellular animals and plants, but their role in the species' life cycle is different. Whereas for plants and animals the complex multicellular phase of the life cycle comprises the reproducing individual, the role of fungal fruiting bodies is restricted to sexual reproduction. Therefore, unlike vegetative mycelia, fruiting bodies are quite ephemeral; their life span usually ranges from a few hours to a few days (except highly resistant bracket fungi, which can be perennial). They support the development and dispersal of meiospores in terrestrial environments by providing protection and a skeleton on which spore-producing basidia or asci develop.

Fruiting bodies of some sort evolved in most clades of terrestrial fungi (Fig. 1A,C), but it is the Dikarya in which the most typical manifestations and $>99 \%$ of the fruiting body-forming species are found, with the two largest groups being the Agaricomycetes and the Pezizomycotina. It is less well known that fruiting bodies have evolved in several other clades as well, such as the Taphrinomycotina, the Pucciniomycotina, and the "Zygomycota." The earliest diverging clades in which fruiting bodies developed are the Mucoromycotina and the Mortierellomycotina, to which Endogone spp. and Modicella spp. belong, respectively. These species form small irregularly lobed or truffle-like structures that contain zygospores (42). Fruiting body-forming members of the Pucciniomycotina (rusts and allies) usually form up to a few millimeters-tall cylindrical or capitate structures (e.g., Phleogena, Gymnosporangium) or crustlike, corticioid layers on the substrate (e.g., Septobasidium). The Taphrinomycotina contain the genus Neolecta, one of the most enigmatic fungi, which forms vividly colored, tongue-like ascocarps $(\underline{6}, \underline{43})$.

Although fruiting bodies can be found in most clades in the Dikarya and even in earlier-diverging clades, the evolutionary origins of their development are not well known. The patchy phylogenetic distribution of fruiting body-forming fungi suggests multiple independent origins, which is further supported by the apparent lack of homologies between fruiting bodies in separate clades. Given the widespread occurrence of fruiting body-producing lineages, however, the alternative hypothesis that the last common ancestor of all Dikarya species was able to produce fruiting bodies cannot be ruled out. 


\section{Diversity and Evolution of Fruiting Body Types}

Fruiting bodies serve two major goals: the protection of developing reproductive organs and the promotion of spore dispersal either by providing an enlarged supporting surface for the sporogenous tissue (e.g., hymenium) and/or by lifting it above ground level. Several alternative solutions have evolved for these tasks during evolution, ranging from simple aggregations of basidia or asci on a hyphal mat (subiculum) to highly integrated complex types that consist of several $(>10)$ distinct cell types (44). The simplest such solutions in the Basidiomycota comprise crust-like, flat fruiting bodies that enclose basidia into a sporogeneous tissue (resupinate type [45-47], e.g., Phanerochaete, Peniophora), whereas in the Ascomycota, cleisthothecia (closed sac-like structures) are the simplest fruiting body types $(\underline{43}, \underline{48})$. Relative to these simple types, a graded series of increasingly more complex morphologies have evolved in several clades (Fig. 1C-E), which will be detailed in the next paragraphs.

The evolution of fruiting body types has followed different principles in the Asco- and Basidiomycota. In the Basidiomycota a clear trend exists from crustlike, resupinate, to more complex morphologies (4547). A great diversity of morphological types derived from the ancestral resupinate types, including coral-like (coralloid), pileate-stipitate (those with cap and stipe), console-shaped (polyporoid and bracket fungi), puffball-like (gasteroid), or reduced cup-shaped (cyphelloid), among others. The pileate-stipitate, typical "mushroomlike" morphologies evolved several times from resupinate ancestors $(\underline{45}-\underline{47}, \underline{49})$, possibly through coral-like intermediates $(\underline{50})$. The pileate-stipitate morphology appears to be a (sub)terminal state, dominating the largest Basidiomycete orders (Agaricales, Boletales, Russulales), possibly due to an optimized surface enlargement of the spore-producing tissue and to efficient protection from precipitation. Pileate-stipitate fruiting bodies show few evolutionary transformations, with the exception of gastromycetation and sequestrization, two related processes denoting the origins of puffball-like fruiting bodies from agaricoid ancestors $(\underline{46}, 49, \underline{51})$. These evolve by the gradual sequestration of the hymenium and often evolve toward an underground, truffle-like lifestyle, probably as an adaptation to dry environments and to zoochory (dispersal by animals). Gasteroid forms in the broad sense (including secotioid and sequestrate) evolved several times from pileate-stipitate ancestors, although they rarely dominate their clades in terms of species diversity, suggesting an internal genetic tendency for their evolution that is coupled with mechanisms that limit their diversification. Another widespread type derived from pileate-stipitate ancestors is the cyphelloid morphology (52). These are cup- or tube-shaped pendant fruiting bodies that most likely evolved via the loss of the stipe and gills of agaricoid species. They are found in several, mostly white-spored clades of the Agaricales.

Ascomycete fruiting bodies evolve from open morphologies toward closed fruiting body types (53). The major morphological types found in the Ascomycota are cleistothecium, perithecium, apothecium, and pseudothecium. The simplest of these is the cleistothecium, a completely closed, usually globose structure that often bears characteristic hyphal appendages. Cleistothecia are characteristic of the Eurotiomycetes (Eurotium, Talaromyces, and allies). Perithecia are globose or flaskshaped structures that open to the outside through the ostiolum, a channel through which spores exit the fruiting body. Perithecia are rarely bigger than a millimeter but can develop in large numbers and can congregate on a common supporting stroma (e.g., in Xylaria species). They are characteristic of the Sordariomycetes and the Laboulbeniomycetes (derived perithecia). Pseudothecia are morphologically similar to perithecia, but they often incorporate tissues from the substrate, and asci are not regularly organized within them. They are found in the Dothideomycetes. Apothecia are completely open, plesiomorphically cup- or disc-shaped fruiting bodies that can reach several centimeters in size. They are found in species of the Pezizomycetes, Leotiomycetes, Orbiliomycetes, Lecanoromycetes, and Lichinomycetes. Several modified and highly derived complex versions of apothecia have evolved, such as morels (Morchella spp.) and truffles (e.g., Tuber spp.). Like gasteroid fruiting bodies of basidiomycetes, truffle-like species evolved several times from apothecial ancestors, probably in response to some widespread selection pressure such as dry climate (54).

\section{Development of Fungal Fruiting Bodies}

The development of fruiting bodies on vegetative mycelia is a major transition in the life of a fungus. It involves a complete reprogramming of hyphal branching patterns and the initiation of a spatially and temporally organized developmental program. Initiation of fruiting body development is part of the sexual reproductive cycle and is thus regulated by genes located in the mating type loci and involves the recognition of compatible nuclei, which happens in basidiomycetes when dikaryotic hyphae develop ( $\underline{48}, \underline{55})$.

Both ascomycete and basidiomycete fruiting bodies develop from aggregated hyphae. In the basidiomycete 
Coprinopsis cinerea, which has been used extensively to study fruiting body development, the first hyphal aggregates are primary hyphal knots, which differentiate primarily in response to light and nutritional signals. Secondary hyphal knots derive from primary hyphal knots, and their differentiation is controlled by both environmental factors and the activity of mating type genes $(55,56)$. Secondary hyphal knots develop into stage 1 primordia ( 0.5 to $1 \mathrm{~mm}$ diameter), which already have cap, stipe, and gill rudiments and develop further into stage 2 primordia ( 2 to $3 \mathrm{~mm}$ tall), then to young and mature fruiting bodies. A characteristic of Coprinopsis spp. is an autolytic phase at the end of development, during which endogenously produced chitinase and glucanase enzymes digest the tissues into a black inky liquid, which might facilitate spore dispersal but may also have other roles (57). In the ascomycete N. crassa, the development of fruiting bodies starts from protoperithecia. Female protoperithecia are induced by nitrogen starvation, fertilized by a compatible male cell (hyphal fragments, micro- or macroconidia), and develop into mature perithecia that contain asci and eight ascospores (48). Variations of these developmental scenarios in various species exist, but the general principles of the early development seem to be conserved across the Asco- and Basidiomycota.

In pileate-stipitate species of the Basidiomycota, a number of developmental types have evolved, differing in the spatial and temporal patterns of tissue differentiation and the extent to which primordia are covered by protective tissues (veils and blemas), among other factors. Based on where in the fruiting body initial primordial cap tissues emerge, epi- and endonodular development can be distinguished (58). In epinodular species, cap rudiments develop on top of the nodulus (globose structures derived from hyphal knots), whereas in endonodular species, the cap is formed within the nodular context. Epinodular development is further divided into exocarpic, where cap and hymenium rudiments are open to the environment, and endocarpic, where the developing hymenial tissues are covered by various hyphal layers. In traditional terms, endonodular and endocarpic types correspond to angiocarpic, whereas exocarpic corresponds to gymnocarpic development, although a strict correspondence is difficult to draw. These protective hyphal sheaths can later vanish or give rise to universal and partial veils, leaving the characteristic patches and rings on mature mushrooms, respectively (58).

Fruiting body morphologies and developmental patterns formed the basis for mushroom classification for a long time. For example, gasteroid basidiomycetes have been classified in the Gasteromycetes on the basis of their shared gross morphology and closed development, although several anatomical, biochemical, or ultrastructural characteristics pointed at a potentially polyphyletic origin $(59,60)$. Fungal classification has been revolutionized by molecular phylogenetic studies, yet developmental characteristics are still useful for species identification and for defining monophyletic groups.

\section{The Genetic Bases of Fruiting Body Development}

Fruiting body development is realized by intricate networks of regulatory and structural genes. A large number of signal transduction pathways and gene regulatory networks orchestrate responses to external (e.g., nutrient availability, light, temperature) and internal (e.g., pheromones) cues (for reviews see references $\underline{48}, \underline{56}$ ) that ultimately lead to the reorganization of the expression patterns of structural and effector genes. Among the environmental stimuli, light is central to the development of fruiting bodies. Light responses are orchestrated to a large extent by blue light receptors, primarily by the photosensor white-collar genes (WC1-2) first identified in $N$. crassa $(\underline{56}, 61, \underline{62})$. One of the key regulatory pathways of fruiting body development is the velvet complex (VelB, VeA, and LaeA in A. nidulans), which controls secondary metabolism and sexual reproduction in response to light stimuli $(\underline{63}, 64)$. The striatininteracting phosphatases and kinases complex has recently been characterized in Sordaria macrospora as a significant component of internal signaling pathways involved in fruiting body development $(\underline{65}, 66)$. Several transcription factors impact fruiting body development, morphology, and morphogenesis (for more details see references 67-70). Structural and effector genes are recruited from the cellular morphogenesis toolkit, among other genes for cell wall modifications, cytoskeletal proteins, and genes involved in protein and cell wall component biosynthesis or coding for cell wallassociated proteins. A number of fruiting body-specific proteins have also been identified, in particular, cell wall proteins such as lectins $(\underline{71}, \underline{72})$, various lectin domaincontaining proteins, and hydrophobins $(\underline{73})$. The roles of several developmentally regulated, but as of now poorly characterized, genes await more thorough understanding. For example, the PriA and Fve proteins were found to be overexpressed in primordia and young fruiting bodies of Lentinula edodes and fruiting bodies of Flammulina velutipes, but their exact role in the developmental process remains an enigma. 


\section{PLANT CELL WALL DECOMPOSITION BY FUNGI}

Most fungi obtain their nutrients from plants, either as saprobes, parasites, or mycorrhizal mutualists. They evolved a wide array of extracellular enzyme systems to attack and decompose complex plant materials and are the most efficient decomposers of lignocellulosic plant cell walls among all microbes. Thus, fungi play an important role in reintroducing fixed carbon into the carbon cycle by degrading dead plant debris and contribute to the functioning of ecosystems all over the world. Several symbiotic interactions also rely on the ability of fungi to decompose plant cell walls. For example, fungus-growing termites and ants use the lignocellulose-degrading ability of various Leucoagaricus, Termitomyces, and Pterula spp. (Agaricales), whereas ruminants harbor large populations of anaerobic Neocallimastigomycota fungi in their rumen. Fungal lignocellulose decomposition is achieved by a variety of mechanisms, including both enzymatic and nonenzymatic systems. The extracellular enzymes of wood-decay fungi received intense industrial interest because of their potential to facilitate the bioconversion of lignocellulosic materials for biofuel production and other industrial applications (e.g., paper industry).

\section{The Diversity of Wood-Decay Types}

Wood decay strategies have been classified in three broad categories in the past: white rot, brown rot, and soft rot (Fig. 1A,C). White rot fungi degrade cellulose, hemicellulose, and lignin components of plant cell walls (74), whereas in soft and brown rot only cellulosic substances are removed and lignin is not appreciably degraded. White and brown rot are typical of Basidiomycetes, whereas soft rot is mainly produced by ascomycetes. This broad classification of decay types has been contested recently based partially on comparative genomics of Basidiomycota (74-76), suggesting that the functional diversity of wood-decay fungi and their role in ecosystems could be better described by a continuum. Several species traditionally classified as white rot fungi lack the enzyme systems to degrade lignin. Among others, Schizophyllum commune, Botryobasidium spp., and Jaapia spp. belong to this category, and although they are usually found on white-rotted wood, their nutritional strategy is unclear. Because of this uncertainty in decay mode and the diversity of nutritional strategies, the definition of white rot is now restricted to species that achieve lignin degradation through the action of class II peroxidases (76) (see below). In general, it is likely that a wide array of strategies for attacking lignocellulose-containing plant cell walls have evolved in various fungi and that these capabilities will support diverse industrial applications when it is known how to leverage them.

The capacity for white rot presumably evolved in the most recent common ancestor of the Auriculariales and more-derived Agaricomycetes (74, 75). Species associated with white rot (e.g., Botryobasidium spp., Tulasnella spp.) can be found in earlier-diverging clades too (Cantharellales), but they lack the hallmark enzymes of white rot (76). The symptoms they produce on rotten wood might reflect an ancestral, soft-rot-like wood decomposition strategy (75). White rot has a single evolutionary origin but has been lost several times. Brown rot fungi, which evolved by the loss of much of the white-rot-specific enzyme complements, originated several times in the Agaricomycetes, among others in the Polyporales, Hymenochaetales, Boletales, and Agaricales (74). Their convergent evolution is underpinned by the loss of several lignocellulose-degrading enzymes, in some cases the loss of complete enzyme/protein families.

\section{The Evolution of Decay-Related Enzyme Families}

Enzyme families involved in lignin decomposition are overrepresented in the genomes of white rot fungi (7479) compared to brown rot and mutualistic fungi. Phylogenetic analyses of these gene families revealed an intricate evolutionary history formed by gene duplications and losses throughout the Basidiomycetes. Numerous gene duplications have been reconstructed in lineages containing white rot fungi, generating the raw material for the evolutionary diversification and potentially for adaptations to various substrates and environmental conditions. However, whether the enormous diversity of these enzymes within the same genome (e.g., up to 40 copies of peroxidases in a genome) reflects a diversity in the expression, activity, or substrate specificity across multiple similar copies is not well understood.

The ability to decay wood components was probably already present in the most recent common ancestor of the Dikarya (Ascomycota plus Basidiomycota), some 700 to 750 million years ago $(\underline{74}, \underline{80}-\underline{82})$, and maybe even earlier. However, it was not until the end of the Carboniferous when high redox-potential enzymes and thus white rot fungi evolved and started to degrade woody substrates on Earth (74). Although molecular clock dating of fungal divergences is notoriously difficult, recent genome-based analyses support the origin of the Agaricomycetes around 290 million years ago. The diversification of white rot fungi at the end of the 
Carboniferous has been linked to the decline in organic carbon accumulation in this era $(\underline{74}, \underline{83})$.

In contrast to white rot fungi, brown rotters degrade the cellulosic materials through nonenzymatic action involving $\mathrm{H}_{2} \mathrm{O}_{2}$ produced by the Fenton reaction. Brown rot fungi possess very few or no ligninolytic enzymes due to extensive gene losses in these gene families, which might be driven by selection for the loss of energetically expensive ligninolytic mechanisms of white rot species (84). Although not able to utilize lignin for energy production, brown rot fungi evolved mechanisms to modify lignin so that cellulose fibrils among lignin polymers become more accessible ( $\underline{85})$. Brown rot fungi are also adapted better to coniferous tree hosts, in contrast to white rot fungi, which are more often found on angiosperm wood $(\underline{86}, \underline{87})$.

Beyond lignocellulose-active enzymes, other cellular pathways are at least as important for the utilization of plant cell wall materials, such as detoxification and membrane transport pathways for neutralizing toxic decomposition intermediates and importing monomers into the cells. These pathways, however, received less attention than the front-end enzyme systems and will require greater scrutiny in future studies.

\section{The Cellular and Genetic Bases of Wood Decay}

Extracellular enzymes play a major role in the degradation of lignocellulosic compounds of plant cell walls by wood-rotting fungi. Plant cell walls are complex and highly diverse composites of various polysaccharides. Fungi evolved a similarly diverse suite of enzymes, mostly glycoside hydrolyses for degrading these components, the most important of which are cellulases, hemicellulases, pectinases that act on main chains of polysaccharides, and accessory "debranching enzymes" that digest polysaccharide side chains. Ligninolytic enzymes (7-89) decompose highly recalcitrant lignin polymers. Enzyme families acting on cellulose chains include endoglucanases, exoglucanases, and beta-glucanases. The oxidoreductive cleavage of cellulose chains by lytic polysaccharide monooxigenases has only recently been discovered as an additional synergistic mechanism of cellulose degradation $(90,91)$. The decomposition of hemicellulose and pectin, due to their complex structure, involves a more diverse set of enzymes: xylanases, mannanases, galactosidases, endoglucanases, cellobiohydrolases, beta-glycosidases, endo- and exopolygalacturonases, pectin and pectate lyases, etc (92). Cellulose, hemicellulose, and pectin degradation have evolved in both the Asco- and Basidiomycota, but there are large differences in the individual species' ability to decompose these compounds. Pectinases, for example, were probably present in the genomes of ca. 750-million-year-old aquatic ancestors of the Dikarya and Chytridiomycota, indicating an ancient adaptation to obtain nutrients from pectin-containing cell walls of early green plants (82).

Lignin, one of the most recalcitrant biopolymers found in nature, is composed of cross-linked aromatic phenol-polymers. The most efficient decomposers of lignin are white rot fungi belonging to the Agaricomycetes, wherein members of the order Polyporales contain the best-characterized white rot species (e.g., Trametes versicolor, Phanerochaete chrysosporium). Less well known but important lignin decomposers are also found in the Agaricales, Boletales, and Russulales. Lignin degradation by white rot fungi is achieved through the generation of oxidative radicals by extracellular enzyme systems. The most important ligninolytic enzymes are class II peroxidases, laccases, and dye decolorizing peroxidases. Based on structural and functional considerations, class II peroxidases are further subdivided into four subfamilies: lignin peroxidases, versatile peroxidases, manganese-peroxidases, and generic peroxidases $(\underline{74}, \underline{89}, 93)$. These high-redoxpotential peroxidases catalyze the oxidation of lignin polymers by hydrogen-peroxide generated by glyoxal oxidases, pyranose oxidases, and aryl-alcohol oxidases (93, 94).

\section{SECONDARY METABOLISM}

Secondary (or specialized) metabolites (SMs) are small molecules whose primary roles involve ecological or environmental interactions as opposed to basic growth, development, and reproduction. For example, SMs secreted by fungi may act as antibiotics or signals to other organisms or alter the availability of nutrients in soil or host tissues. Fungal SMs can be quite diverse, similar to plants, and are in part distributed among fungi according to ecological traits rather than species relationships. The origin and evolution of secondary metabolic pathways in fungi reflect broader patterns of genome remodeling in a biochemical arms race with competitors and hosts.

Only a small proportion of the adaptive biological functions of SMs are characterized (it is sometimes argued that most have no current functions [95]), but a subset of these is known to have important ecological roles (96). As with plants, the most obvious roles for SMs are defense and competition (Fig. 2). Although most classes of antibiotic pharmaceuticals are bacterial 


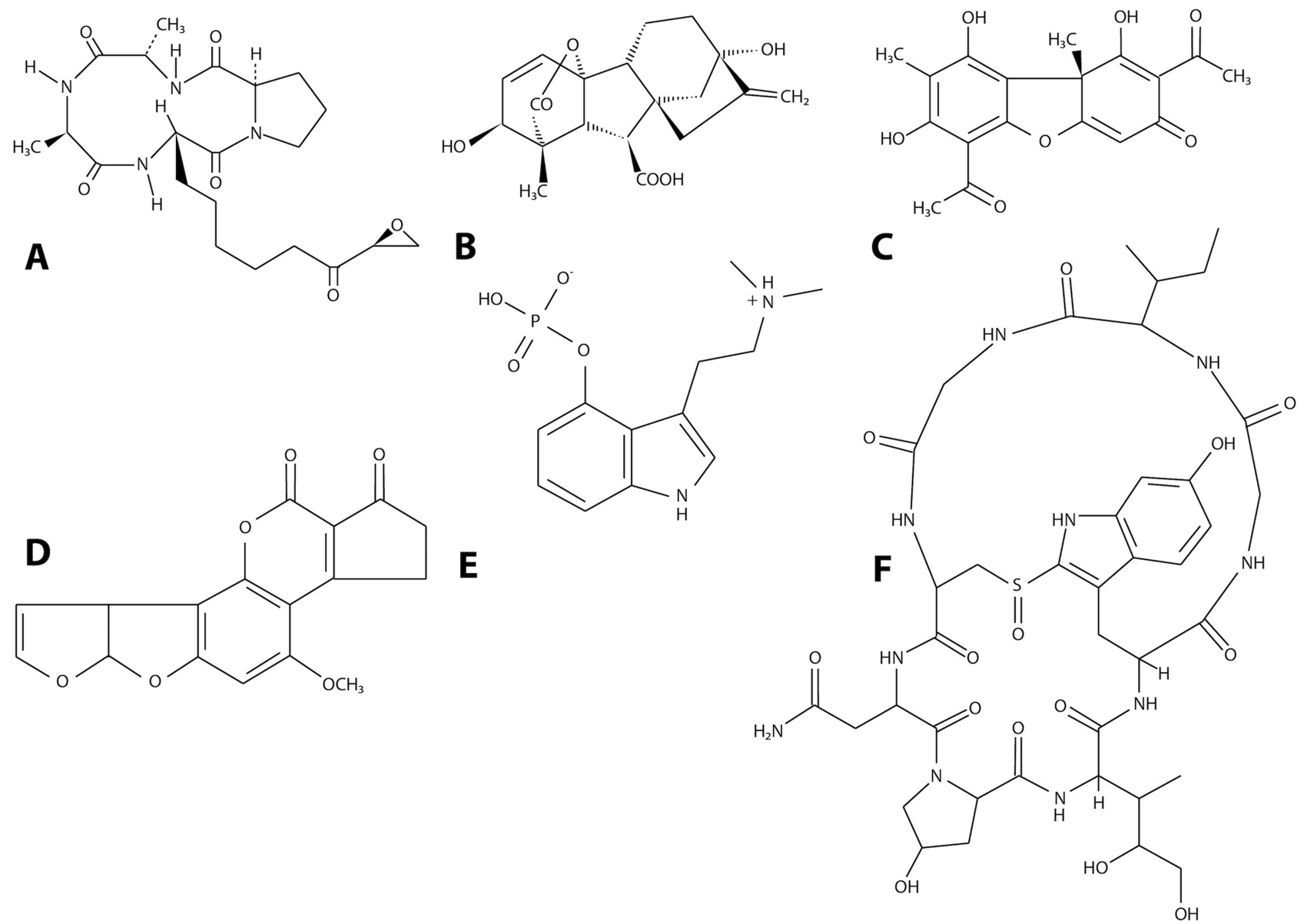

FIGURE 2 Secondary metabolites produced by fungi. (A) HC toxin is a nonribosomal peptide virulence factor produced by plant pathogens such as the Northern corn leaf spot fungus, Cochliobolus carbonum. (B) Gibberellic acid is a diterpene-derived plant growth hormone produced by some Fusarium spp. (e.g., Fusarium moniliforme = Gibberella fujikuroi), which leads to growth defects in grass seedlings. (C) Usnic acid is a common polyketide secondary metabolite thought to protect against biotic and abiotic stress in many lichens. (D) Aflatoxin B1 is a highly carcinogenic polyketide produced by Aspergillus molds that spoils grain and peanut harvests. (E) Psilocybin is a hallucinogenic indole alkaloid produced by a variety of mushrooms. (F) Alpha amanitin is a deadly peptide alkaloid that inhibits RNA polymerase II, produced by diverse mushroom-forming fungi.

in origin, antibiotics are nonetheless important products of fungi (97). Beta-lactams, including penicillin and cephalosporins, are among the few fungus-derived antibiotics that are suitable for human use. The existence of a large number of SMs is suggested by homologs of known SM genes found in the growing database of whole-genome sequences, but they have not yet been observed to be expressed (98). Cryptic antifungal and antibiotic fungal SMs can be uncovered via dual-plating experiments, in which fungi paired with other microorganisms secrete compounds that inhibit growth of the competitor or via inducing the expression of "silent" SM genes (99). However, specific SM-mediated ecological interactions are not usually documented in their natural context.

Among the main exceptions to this lack of tested functionality are SMs produced by fungi that act as pathogens of plants. For example, plant pathogens often secrete SM toxins to directly induce plant cell death during necrotrophic growth (100). Cochliobolus carbonum secretes the host-selective HC toxin, which prevents induction of normal defenses in maize (101). Other plant pathogens manipulate the host's internal signals involved in growth and programmed cell death. 
For example, Botrytis cinerea and other fungi secrete the plant hormones abscisic acid and ethylene during necrotrophic pathogenesis (102).

Some fungal SMs appear to be involved in fungusanimal interactions. Nematodes and arthropods are the main predators of fungi, so it is likely that they are often the targets of SMs that affect animal neurotransmitter signaling pathways. For example, psilocin and muscarine are produced by a number of mushroom-forming basidiomycetes and bind to serotonin and acetylcholine receptors, respectively (103). Ascomycete molds also produce larvicidal compounds, and a mutant Aspergillus that produces few SMs due to deletion of a global regulator of SM pathways is preferred by fungivorous arthropods (104).

These same antimicrobial and competitive functions can also be of benefit to plant hosts of symbiotic fungi. Grass endophytes of Clavicipitaceae have long been studied for their antiherbivory toxins, which can increase fitness and dominance of infected plants (105). Surprisingly, some endophytes have been recently shown to produce the same SMs as their hosts and may compensate for reduced production of these SMs by the plants when they are allocating resources to, for example, reproduction (106). In general, endophytes are prolific producers of diverse metabolites and are considered "acquired immune systems" of the plants that benefit from them (107).

Because fungi are absorptive-feeding organisms, fungal growth is constrained by environmental conditions and competition that affect the availability of nutrients. SMs play a role in increasing access to limiting elements such as iron. Siderophores are molecules with especially high affinity for binding iron (108). There are a number of independently evolved siderophores in fungi. Siderophores are particularly important to animal-pathogenic fungi that compete with both hosts and their commensal microorganisms for limited iron $(\underline{109}, 110)$.

SMs are also important for protection from environmental stresses such as desiccation and radiation. Melanins are amorphous SM polymers synthesized from various precursors, which absorb radiation and create a resistant barrier to dehydration and mechanical damage (111). For example, the melanized rhizomorphs of Armillaria spp. allow the fungus to cross long distances in exposed, low-moisture environments to access new substrates (112), and melanized sclerotia enable pathogens and symbionts of annual plants to survive and overwinter in detritus and soil. The tendency of melanins to neutralize radical molecules may also protect melanized yeasts against similar molecules used by immune macrophages and soil predators such as amoeba (113). Lichenized fungi, on the other hand, endure chronic environmental exposure and consequently utilize numerous SMs to reduce the damaging effect of light exposure (114).

\section{Major Types of Secondary Metabolites}

Five main classes of fungal SMs have been studied in depth: peptides, polyketides, peptide-polyketide hybrids, terpenes, and alkaloids. Peptide SMs are usually synthesized by special polymerizing enzymes called nonribosomal peptide synthetases but are occasionally produced from repetitive DNA templates by cleavage of the resulting polypeptide sequences. Examples of nonribosomal peptide synthetase-produced SMs include the beta-lactam antibiotics such as penicillin and cephalosporin and the immunosuppressant cyclosporin (115). Amatoxins, the deadly RNA transcription inhibitors produced by death angel mushrooms such as Amanita bisporigera, are produced by cleaving 35 amino acid proteins into octopeptides, which are then cyclized by a mechanism that is not fully understood (116). Polyketide synthetases, the most abundant SM-producing enzymes in fungi, polymerize fatty acid subunits rather than amino acid subunits like the nonribosomal peptide synthetases $(\underline{115})$. A basic polyketide chain can be modified with functional group "decorations" and formed in rings by other enzymes in these pathways to produce a wide range of compounds. Among these are the aflatoxins from Aspergillus spp., which are toxic and costly contaminants of maize, peanut, and other crops (117), and statins from diverse species, originally targeted as pharmaceuticals to reduce cholesterol synthesis $(118)$.

Terpenes are volatile or nonvolatile compounds produced from isoprenoid subunits and include both the trichothecene mycotoxins from Fusarium spp. and desirable flavor compounds in edible mushrooms (119, 120). Gibberellic acids are terpenoid hormones first characterized in Gibberella (Fusarium) fujikuroi-infected rice as the cause of hypertrophy symptoms leading to extensive crop losses. Alkaloids are diverse nitrogencontaining SMs that are often associated with toxicity and feeding deterrence against herbivores and fungivores. Vertically transmitted fungal endophytes of grasses, for example, produce from amino acid precursors four classes of alkaloids that are toxic to mammals and invertebrates. Among these, insecticidal loline alkaloids are derived from L-proline and L-homoserine, and livestock/ human-intoxicating indole and indole diterpene alkaloids, which interfere with neural and vascular processes, 
are derived from L-tryptophan (121). Notable toxicoses caused by indole-based alkaloids include "ryegrass staggers" in livestock caused by lolitrem B, and ergotism and related syndromes in humans and animals caused by ergot alkaloids produced by Claviceps purpurea (ergot) and clavicipitaceous grass endophytes. Psilocin from "magic" mushrooms and lysergic acid diethylamide (LSD) are indole alkaloids that have additionally influenced human culture and religion through their hallucinogenic activity (122). Due to their high potential for bioactivity, fungal alkaloids have contributed a number of therapeutic drugs such as ergometrine, an ergot alkaloid that revolutionized medical control over postpartum hemorrhage, and a number of promising anticancer drugs.

\section{The Evolution of Secondary Metabolism in Fungi}

The roles and extent of secondary metabolism in fungi vary widely by lineage. Filamentous Ascomycota contain by far the majority of known SM genes, while ascomycete yeasts, Basidiomycetes, Zygomycetes, and chytrids have few or none of the classes described above $(123)$. Fungal metabolic pathways involved in ecological processes are often encoded in "gene clusters" (124). For example, most enzymes, regulators, and transporters required for production and delivery of SMs are the products of genes in close physical proximity on chromosomes. The evolution of such gene clusters is highly dynamic; specific gene clusters are usually distributed among only a fraction of fungal taxa but can be found in taxa that are distantly related (125). This distribution of gene clusters reflects a history of horizontal gene transfer, along with rapid degeneration, loss, and remodeling of metabolic pathways. Numerous SM gene clusters appear to have been horizontally transferred between distantly related fungi (126, 127). For example, the 24-gene sterigmatocystin cluster in Podospora anserina (Sordariomycetes) is highly similar to that in A. nidulans (Eurotiomycetes) both in gene order and nucleotide sequence (128). However, within Aspergillus, homologous clusters are variable in their presence and composition. Rapid rearrangement and degeneration of these clusters resulted in a diversity of producers and nonproducers of aflatoxins among Aspergillus species and the virulence factor dothistromin in the pine pathogen Dothistroma septosporum (129). Secondary metabolism gene clusters in fungi will continue to be an important topic of evolutionary, ecological, and pharmacological studies in the coming years.

\section{MYCORRHIZAE}

One of the major traits of fungi is their ability to form symbiotic interactions with plants. These interactions can be either parasitic or mutually beneficial, and many of them probably evolved in parallel with the colonization of the land by plants. It has been long suggested that the colonization of land by plants has been aided by early mutualistic fungi (130). There are several types of mutualistic interactions between plants and fungi, among which mycorrhizae formed by land plants and fungi are the most frequent. Although plant-fungal symbioses played a crucial role and were a driving force in the evolution of both partners, here we focus on the evolution, physiology, and anatomy of mycorrhizae from a fungal perspective.

There are several possible definitions of "mycorrhizae," and while there might be debates about them, the main types of mycorrhizal interactions are relatively well defined. The term itself means "fungus-root" and was coined by Frank (1885) in his landmark work in which he also posited the importance and mutual benefits of reciprocal nutrient exchange through mycorrhizae (131, 132). According to Trappe's definition (179), mycorrhizae are "dual organs of absorption formed when symbiotic fungi inhabit healthy absorbing organs (roots, rhizomes, or thalli) of most terrestrial plants and many aquatics and epiphytes." The use of the phrase "most terrestrial plants" is not exaggeration at all: the majority of land plants form mycorrhizae: $90 \%$ of the plant families are mycorrhizal, as are 70 to $80 \%$ of known plants on the species level (133-137). The main function of mycorrhizae is reciprocal nutrient exchange between the partners: using their extraradical hyphae, fungi mobilize and/or uptake nutrients from the soil, transport them into the roots, and thus to the plants, while the plants transfer assimilated sugars to the fungal partner $(133,138)$. The most important nutrients mobilized and transported from the soil are phosphate, nitrogen, and water. Nutrient mobilization, however, depends on the type of mycorrhiza, the fungal partner, the habitat, and the environment. Hence, there is a fine balance in the dominance and importance of different processes, mycorrhizal partners, and the main nutrients exchanged between them in different habitats and ecosystems $(\underline{133}, \underline{138}, \underline{139})$.

\section{Diversity of Mycorrhizal Types}

Coining a generic definition of mycorrhizae is complicated by the functional and anatomical diversity of mycorrhizal interactions. The wide range of morphological types of mycorrhizae can be classified as two 
main forms of fungal colonization: in endomycorrhizae the fungal hyphae penetrate the root cells, whereas in ectomycorrhizae (ECM) the fungi colonize the intercellular spaces only. There are clear differences between these two types, not only in gross anatomy, but also in characteristic enzyme sets used by the fungi. Endomycorrhizae can be further subdivided into arbuscular mycorrhizae (AM), orchid mycorrhizae, and ericoid mycorrhizae (ERM), each characteristic of certain plant lineages $(133,134)$. Many other types characteristic of smaller plant groups exist (134). For example, arbutoid and monotropid mycorrhizae are ectendomycorrhizae showing main structural characteristics of ECM but also hyphal colonization of plant cells (133). The plants forming these mycorrhizae are mycotrophic: they are not or are not completely autotrophic and gain assimilates from other plants mostly through connections with ECM fungi.

ERM are endomycorrhizae formed by plants in the Ericales and various asco- and basidiomycetes $(133,134)$. The best-known fungal taxa are found in the ascomycete genera Hymenoscyphus, Cadophora, and Oidiodendron, but Sebacina spp. and other basidiomycetes have also been identified as ERM fungi (140). Some Ericales have specialized, extremely thin, simple roots $(133,141)$ and grow in habitats with a very slow organic turnover, which makes them dependent on mycorrhizal partners with good saprobic capacities.

Orchid mycorrhiza (ORM) is also an endomycorrhizal interaction, with characteristic intracellular hyphal forms such as the pelotons (densely coiling intracellular hyphal mass) and the moniliform hyphae $(133,141)$. Orchids depend obligately on their symbiotic fungal partners. They require the presence of fungi for the germination of their seeds and the development of the protocorm stage (133). Some orchids are mycoheterotrophic due to the complete or incomplete loss of photosynthetic capacity in the adult stage or the insufficient amount of light in their habitats. These mycoheterotrophic species fully or partly rely nutritionally on fungi that form mycorrhizae with autotrophic plants (133). The decomposition processes driven by fungal partners with strong saprobic capacities also play a role in the carbon supply to the plants in ORM. Although the association between orchids and fungi had been known for a long time, the mutualistic reciprocal transport was proven only 10 years ago: in addition to the fungal $\mathrm{N}$ transport to the plant, a reciprocal $\mathrm{C}$ exchange between the two partners has also been observed (142). The most widespread orchid mycorrhizal fungi are found in the Cantharellales (Basidiomycota), e.g., Rhizoctonia, Tulasnella, and Ceratobasidium. However, a huge diversity of other, mostly basidiomycete fungi can also be detected in orchid roots. Even members of the Atractelliomycetes (Pucciniomycotina) were proven to colonize and form an intracellular interface in terrestrial orchid roots $(\underline{143})$.

\section{Arbuscular Mycorrhiza (AM)}

$\mathrm{AM}$ is the most widespread mycorrhiza type and probably the most frequent symbiosis on Earth $(144,145)$. AM is exclusively formed by obligate biotrophic fungi of the Glomeromycota, while high numbers of plant species from almost all mainland plant groups form this mycorrhizal type $(133,136)$. The Glomeromycota is a relatively small group with approximately 230 known species (146). One of the main benefits for the plants in this symbiosis is the phosphate transferred by AM fungi to the plants (133). Although these fungi harbor genes related to sexual reproduction $(147,148)$ no sexual stage is known. AM is an endomycorrhiza named after the tree-like arbuscules formed in the plant cells (133). Plant cells completely reorganize themselves during colonization by the AM hyphae, and the colonization itself depends highly on the plant, among other factors, because PCWDEs are missing from the genome of Rhizophagus irregularis (147). Precolonization recognition processes of plant and fungal partners in mycorrhizal interactions are best known in the case of the AM. Here, fungi release diffusible factors, e.g., lipochitooligosaccharides (the "myc-factors"), acting as elicitors and signals recognized by the plant, while the plants secrete diverse compounds such as strigolactons, which influence the fungus before colonization (149). The plant membrane around the arbuscules has many special characteristics; e.g., specific plant phosphate transporters are located on the periarbuscular membrane. The arbuscule and the perisymbiotic membrane share many similar features with haustoria of intracellular biotrophic pathogens such as downy mildews, powdery mildews, and rust fungi (150). Nevertheless, beneficial mycorrhizal and parasitic interactions have clearly different functional and regulatory features $(150,151)$.

Fossilized spores and arbuscular structures and the capability of the basal green plants to form AM (152158) suggest that AM fungi helped plants to conquer land (159). The clade of AM fungi, Glomeromycotina (160), branched off approximately 400 to 450 million years ago in the phylogeny of fungi (161), and the Glomeromycotina groups with Mucoromycotina (160, $162,163)$. This is especially interesting considering that Mucoromycotina fungi were recently shown to be mu- 
tualistic symbionts of basal plant groups (123, 164-166) and that hyphal structures resembling mucoralean fungi were also reported from plant fossils (167). These findings seem to change the paradigm that the Glomeromycotina was the only ancient mycorrhizal lineage. Nevertheless, it seems that the capacity to form AM evolved only once in fungal evolution, in the ancestor of the Glomeromycotina clade.

Although we have detailed data on the molecular mechanisms of AM symbiosis, ranging from the presymbiotic phase through root colonization and arbuscule development, and there is information about the shared genomic toolkits of AM-forming plants (168), our knowledge of the genomic backgrounds of AM formation is limited. For several reasons, including the relatively big ( $\sim 140$ to $150 \mathrm{Mb})$ genomes with a high number of repetitive elements, the genome of only a single species, $R$. irregularis (once known as Glomus intraradices), has been completely sequenced $(147,163)$.

\section{Ectomycorrhiza (ECM)}

$\mathrm{ECM}$ is the most dominant type in temperate forest ecosystems $(133,137,169)$, although it can be abundant in tropical areas too $(\underline{170})$. Interestingly, only around $2 \%$ of plant species, mostly woody plants (e.g., Fagaceae, Pinaceae), form ECM (133, 137). In ECM the fungal partner forms a mantle on the surface of the colonized root tips, and the exchange of nutrients takes place in an intercellular interface between the plant and fungus, called the Hartig-net. The Hartig-net is a coenocytic structure (171) formed around the epidermal and/or cortical cell layers of the roots (133). Based on the diversity in ECM morphology, including characteristics of emanating elements and rhizomorph structures, ECM have been assigned to different exploration types (172), which probably reflect functional differences among ECM fungi.

Several ECM fungal lineages appeared during the evolution of the Dikarya, to which the majority of ECM fungi belong. The capacity to form ECM evolved independently in the Basidiomycota (e.g., Amanita muscaria) and the Ascomycota (e.g., Tuber melanosporum), according to some estimates 78 to 82 times (137). Compared to $\mathrm{AM}$, the ECM association is evolutionarily younger, around 100 to 170 million years old. ECM groups have evolved from nutritionally diverse ancestors, including white rot and brown rot fungi and plant pathogens (173). The comparative analyses of the first two genome sequences of ECM fungi, the basidiomycete Laccaria bicolor and the ascomycete truffle T. melanosporum, revealed striking differences between the two
ECM species $(174,175)$. This heterogeneity was further supported by the comparative analysis of 49 fungal genomes representing 11 ECM, 3 ORM, and 1 ERM species of fungi, alongside several saprobes and plant pathogens (173) and the genome of Cenococcum geophilum, one of the most widespread ECM-forming Ascomycota.

Consistent with the independent origins of ECM fungi, the genetic toolkits underlying the mycorrhizal interaction have also evolved independently. Thus, identifying the genetic bases of mycorrhiza formation is challenging, which is further complicated by the high proportion ( 7 to $38 \%$ ) of orphan genes (i.e., genes showing no homology with any other known genes) induced during mycorrhiza formation. Their abundance might be explained either by the recent origins of the lifestyle and the underlying genes or by the high rate of the evolution of interactionrelated genes. One conserved pattern across ECM lineages is the lower diversity of PCWDEs compared to related wood-decaying or parasitic species. Many lineages have lost most of their PCWDE complement, which indicates reduced saprotrophic capabilities of these fungi. Nevertheless, PCWDEs play a crucial role in root colonization and in nutrient mobilization in the soil, and their presence suggests that many lineages of ECM fungi retain some saprotrophic potential. In contrast to ECM, ERM and ORM fungi possess high numbers of PCWDE genes and have strong saprobic capacities (173). The genetic bases of mycorrhiza formation comprise complex pathways of secreted proteins, effectors, regulators, PCWDEs, and several hitherto unknown components. Small secreted proteins are particularly abundant in ECM species and are upregulated during mycorrhiza formation in high numbers (176). These might be involved in controlling host defense mechanisms during the establishment of the mycorrhizal interaction. For example, MiSSP7 of L. bicolor interacts with jasmonic acid signaling repressors of the host plant (this pathway modulates plant-microbe interactions in plants), which promotes symbiosis (177). The wide array of mycorrhiza-induced effector-like secreted small proteins suggests that several other aspects of regulating the interaction and maintaining the fine balance between mutualism and parasitism exist and remain to be identified $(\underline{177}, \underline{178})$.

\section{EVOLUTIONARY CONVERGENCE IN FUNGI}

Fungi show evolutionary convergence at multiple levels. All of the traits considered here result from convergent evolution at various taxonomic levels. For example, fruiting bodies evolved in the Asco-, Basidio-, and $\mathrm{Mu}-$ 
coromycota, but also show convergence at finer scales in the Basidiomycota, where the agaricoid morphology has evolved in at least seven orders independently. Convergence can be observed both in trait gains and losses, the latter being naturally more common and including the repeated evolution of brown rot lineages from white rot ancestors through losses of PCWDE genes or the parallel reduction of the multicellular phase in the life cycles of yeasts. On the other hand, surprisingly similar phenotypic solutions for polarized hyphal growth and fruiting body formation evolved several times independently. The evolution of ECM associations is marked by both gains and losses: many PCWDE genes have been lost, whereas genes involved in ECM formation have been gained in a lineage-specific manner in ECM clades $(169,173)$. It is therefore important to consider the genetic mechanisms of phenotypic convergence in fungi. Parallel losses of conserved genetic toolkits provide a straightforward explanation for the repeated evolution of similar phenotypes. For instance, the loss of ligninolyic and other PCWDE genes resulted in selective nonenzymatic degradation of cellulosic plant cell wall components by brown rot fungi, which presumably, combined with the parallel elaboration of as yet unknown compensatory biochemical activities, resulted in similar wood-degrading strategies in multiple clades of these fungi.

Similarly, the evolution of major yeast lineages has been marked primarily by gene loss and limited genetic novelty associated with the morphological transition. However, phylogenetic patterns suggest that phenotypic similarity evolved independently in multiple yeast-like clades, fruiting body-forming groups, or hyphae, which prefigures mechanisms for gaining similar phenotypes independently in a convergent or parallel manner. Consistent with the predictions of convergent evolutionary theory, independently evolved ECM lineages share little of the known genetic innovations involved in ECM formation $(169,173)$. On the other hand, classical convergence fails to explain the convergent evolution of polarized hyphal growth or fruiting body formation. For these cases, a continuum of mechanisms for convergent evolution needs to be considered, ranging from the parallel cooption of orthologous genes and pathways for similar functions to underlying latent homologies or the evolution of divergent genetic toolkits.

\section{REFERENCES}

1. Harris SD, Momany M. 2004. Polarity in filamentous fungi: moving beyond the yeast paradigm. Fungal Genet Biol 41:391-400 http://dx.doi .org/10.1016/j.fgb.2003.11.007.

2. Harris SD. 2011. Hyphal morphogenesis: an evolutionary perspective. Fungal Biol 115:475-484 http://dx.doi.org/10.1016/j.funbio.2011.02 .002 .
3. Dee JM, Mollicone M, Longcore JE, Roberson RW, Berbee ML. 2015. Cytology and molecular phylogenetics of Monoblepharidomycetes provide evidence for multiple independent origins of the hyphal habit in the Fungi. Mycologia 107:710-728 http://dx.doi.org/10.3852/14-275.

4. Moore D. 2013. Fungal Biology in the Origin and Emergence of Life. Cambridge University Press, Cambridge, United Kingdom. http://dx.doi .org/10.1017/CBO9781139524049

5. Jedd G. 2011. Fungal evo-devo: organelles and multicellular complexity. Trends Cell Biol 21:12-19 http://dx.doi.org/10.1016/j.tcb.2010 .09 .001 .

6. Healy RA, Kumar TK, Hewitt DA, McLaughlin DJ. 2013. Functional and phylogenetic implications of septal pore ultrastructure in the ascoma of Neolecta vitellina. Mycologia 105:802-813 http://dx.doi.org/10.3852 112-347.

7. Lew RR. 2011. How does a hypha grow? The biophysics of pressurized growth in fungi. Nat Rev Microbiol 9:509-518 http://dx.doi.org/10.1038 Inrmicro2591.

8. Harris SD. 2008. Branching of fungal hyphae: regulation, mechanisms and comparison with other branching systems. Mycologia 100:823-832 http://dx.doi.org/10.3852/08-177.

9. Wendland J. 2001. Comparison of morphogenetic networks of filamentous fungi and yeast. Fungal Genet Biol 34:63-82 http://dx.doi.org /10.1006/fgbi.2001.1290.

10. Bartnicki-Garcia S, Hergert F, Gierz G. 1989. Computer simulation of fungal morphogenesis and the mathematical basis for hyphal(tip) growth. Protoplasma 153:46-57 http://dx.doi.org/10.1007/BF01322464.

11. Bartnicki-Garcia S. 2002. Hyphal Tip Growth: Outstanding Questions. Marcel Dekker, New York, NY.

12. Berepiki A, Lichius A, Read ND. 2011. Actin organization and dynamics in filamentous fungi. Nat Rev Microbiol 9:876-887 http://dx.doi .org/10.1038/nrmicro2666.

13. Virag A, Harris SD. 2006. The Spitzenkörper: a molecular perspective. Mycol Res 110:4-13 http://dx.doi.org/10.1016/j.mycres.2005.09.005.

14. Harris SD. 2001. Septum formation in Aspergillus nidulans. Curr Opin Microbiol 4:736-739 http://dx.doi.org/10.1016/S1369-5274(01) 00276-4.

15. Ruiz-Herrera J. 2012. Dimorphic Fungi: Their Importance as Models for Differentiation and Fungal Pathogenesis. Bentham Science Publishers, Dubai, United Arab Emirates.

16. Dickinson JR. 2005. Are yeasts free-living unicellular eukaryotes? Lett Appl Microbiol 41:445-447 http://dx.doi.org/10.1111/j.1472-765X .2005.01798.x.

17. Nagy LG, Ohm RA, Kovács GM, Floudas D, Riley R, Gácser A, Sipiczki M, Davis JM, Doty SL, de Hoog GS, Lang BF, Spatafora JW, Martin FM, Grigoriev IV, Hibbett DS. 2014. Latent homology and convergent regulatory evolution underlies the repeated emergence of yeasts. Nat Commun 5:4471 http://dx.doi.org/10.1038/ncomms5471.

18. Nemecek JC, Wüthrich M, Klein BS. 2006. Global control of dimorphism and virulence in fungi. Science 312:583-588 http://dx.doi.org /10.1126/science.1124105.

19. Lewis ER, Bowers JR, Barker BM. 2015. Dust devil: the life and times of the fungus that causes valley fever. PLoS Pathog 11:e1004762 http://dx.doi.org/10.1371/journal.ppat.1004762.

20. Wang L, Lin X. 2012. Morphogenesis in fungal pathogenicity: shape, size, and surface. PLoS Pathog 8:e1003027 http://dx.doi.org/10.1371 journal.ppat.1003027.

21. Gauthier GM. 2015. Dimorphism in fungal pathogens of mammals, plants, and insects. PLoS Pathog 11:e1004608 http://dx.doi.org/10.1371 journal.ppat.1004608.

22. Gauthier G, Klein BS. 2008. Insights into fungal morphogenesis and immune evasion: fungal conidia, when situated in mammalian lungs, may switch from mold to pathogenic yeasts or spore-forming spherules. $\mathrm{Mi}$ crobe Wash DC 3:416-423 http://dx.doi.org/10.1128/microbe.3.416.1. 
23. Restrepo A, Salazar ME, Cano LE, Stover EP, Feldman D, Stevens DA. 1984. Estrogens inhibit mycelium-to-yeast transformation in the fungus Paracoccidioides brasiliensis: implications for resistance of females to paracoccidioidomycosis. Infect Immun 46:346-353.

24. Youngchim S, Nosanchuk JD, Pornsuwan S, Kajiwara S, Vanittanakom N. 2013. The role of L-DOPA on melanization and mycelial production in Malassezia furfur. PLoS One 8:e63764 http://dx.doi .org/10.1371/journal.pone.0063764.

25. Brown GD, Gordon S. 2005. Immune recognition of fungal betaglucans. Cell Microbiol 7:471-479 http://dx.doi.org/10.1111/j.1462 -5822.2005.00505.x.

26. Hogan LH, Klein BS. 1994. Altered expression of surface alpha-1,3glucan in genetically related strains of Blastomyces dermatitidis that differ in virulence. Infect Immun 62:3543-3546.

27. Rappleye CA, Eissenberg LG, Goldman WE. 2007. Histoplasma capsulatum alpha-(1,3)-glucan blocks innate immune recognition by the beta-glucan receptor. Proc Natl Acad Sci USA 104:1366-1370 http://dx .doi.org/10.1073/pnas.0609848104.

28. Holbrook ED, Smolnycki KA, Youseff BH, Rappleye CA. 2013. Redundant catalases detoxify phagocyte reactive oxygen and facilitate Histoplasma capsulatum pathogenesis. Infect Immun 81:2334-2346 http://dx.doi.org/10.1128/IAI.00173-13.

29. Chao LY, Rine J, Marletta MA. 2008. Spectroscopic and kinetic studies of Nor1, a cytochrome P450 nitric oxide reductase from the fungal pathogen Histoplasma capsulatum. Arch Biochem Biophys 480:132-137 http://dx.doi.org/10.1016/j.abb.2008.09.001.

30. Campos EG, Jesuino RS, Dantas AS, Brígido MM, Felipe MS. 2005. Oxidative stress response in Paracoccidioides brasiliensis. Genet Mol Res 4:409-429.

31. Sims CR, Ostrosky-Zeichner L, Rex JH. 2005. Invasive candidiasis in immunocompromised hospitalized patients. Arch Med Res 36:660-671 http://dx.doi.org/10.1016/j.arcmed.2005.05.015.

32. Trofa D, Gácser A, Nosanchuk JD. 2008. Candida parapsilosis, an emerging fungal pathogen. Clin Microbiol Rev 21:606-625 http://dx.doi .org/10.1128/CMR.00013-08.

33. Goldani LZ, Santos RP. 2010. Candida tropicalis as an emerging pathogen in Candida meningitis: case report and review. Braz J Infect Dis 14:631-633.

34. Sullivan D, Coleman D. 1997. Candida dubliniensis: an emerging opportunistic pathogen. Curr Top Med Mycol 8:15-25.

35. Thompson DS, Carlisle PL, Kadosh D. 2011. Coevolution of morphology and virulence in Candida species. Eukaryot Cell 10:1173-1182 http://dx.doi.org/10.1128/EC.05085-11.

36. Li CH, Cervantes M, Springer DJ, Boekhout T, Ruiz-Vazquez RM, Torres-Martinez SR, Heitman J, Lee SC. 2011. Sporangiospore size dimorphism is linked to virulence of Mucor circinelloides. PLoS Pathog 7:e1002086 http://dx.doi.org/10.1371/journal.ppat.1002086.

37. Lillis JV, Dawson ES, Chang R, White CR Jr. 2010. Disseminated dermal Trichophyton rubrum infection: an expression of dermatophyte dimorphism? J Cutan Pathol 37:1168-1169 http://dx.doi.org/10.1111 j.1600-0560.2009.01355.x.

38. Nadal M, García-Pedrajas MD, Gold SE. 2008. Dimorphism in fungal plant pathogens. FEMS Microbiol Lett 284:127-134 http://dx.doi.org /10.1111/j.1574-6968.2008.01173.x.

39. Cissé OH, Almeida JM, Fonseca A, Kumar AA, Salojärvi J, Overmyer K, Hauser PM, Pagni M. 2013. Genome sequencing of the plant pathogen Taphrina deformans, the causal agent of peach leaf curl. MBio 4:e0005513 http://dx.doi.org/10.1128/mBio.00055-13.

40. Vollmeister E, Schipper K, Baumann S, Haag C, Pohlmann T, Stock J, Feldbrügge M. 2012. Fungal development of the plant pathogen Ustilago maydis. FEMS Microbiol Rev 36:59-77 http://dx.doi.org/10.1111/j.1574 -6976.2011.00296.x.

41. Naruzawa ES, Bernier L. 2014. Control of yeast-mycelium dimorphism in vitro in Dutch elm disease fungi by manipulation of specific external stimuli. Fungal Biol 118:872-884 http://dx.doi.org/10.1016 lj.funbio.2014.07.006.

42. Smith ME, Gryganskyi A, Bonito G, Nouhra E, Moreno-Arroyo B, Benny G. 2013. Phylogenetic analysis of the genus Modicella reveals an independent evolutionary origin of sporocarp-forming fungi in the Mortierellales. Fungal Genet Biol 61:61-68 http://dx.doi.org/10.1016 /j.fgb.2013.10.001.

43. Liu YJ, Hall BD. 2004. Body plan evolution of ascomycetes, as inferred from an RNA polymerase II phylogeny. Proc Natl Acad Sci USA 101:4507-4512 http://dx.doi.org/10.1073/pnas.0400938101.

44. Pukkila PJ. 2011. Coprinopsis cinerea. Curr Biol 21:R616-R617 http://dx.doi.org/10.1016/j.cub.2011.05.042.

45. Binder M, Hibbett DS, Larsson K-H, Larsson E, Langer E. 2005. The phylogenetic distribution of resupinate forms across the major clades of mushroom-forming fungi (Homobasidiomycetes). Syst Biodivers 3:113$157 \mathrm{http}: / / \mathrm{dx}$.doi.org/10.1017/S1477200005001623.

46. Hibbett D. 2004. Trends in morphological evolution in homobasidiomycetes inferred using maximum likelihood: a comparison of binary and multistate approaches. Syst Biol 53:889-903 http://dx.doi.org 110.1080/10635150490522610.

47. Hibbett DS, Binder M. 2002. Evolution of complex fruiting-body morphologies in homobasidiomycetes. Proc Biol Sci 269:1963-1969.

48. Pöggeler S, Nowrousian MKU. 2006. Fruiting-body development in Ascomycetes, p 325-355. In Esser K (ed), The Mycota: Growth, Differentiation and Sexuality. Springer-Verlag, Berlin, Germany. http://dx.doi .org/10.1007/3-540-28135-5_16

49. Hibbett DS. 2007. After the gold rush, or before the flood? Evolutionary morphology of mushroom-forming fungi (Agaricomycetes) in the early 21st century. Mycol Res 111:1001-1018 http://dx.doi.org/10.1016 /j.mycres.2007.01.012.

50. Miller OK. 1971. The relationship of cultural characters to the taxonomy of the agarics, p 197-215. In Petersen RH (ed), Evolution in the Higher Basidiomycetes. University of Tennessee Press, Knoxville, TN.

51. Peintner U, Bougher NL, Castellano MA, Moncalvo JM, Moser MM, Trappe JM, Vilgalys R. 2001. Multiple origins of sequestrate fungi related to Cortinarius (Cortinariaceae). Am J Bot 88:2168-2179 http://dx.doi .org $/ 10.2307 / 3558378$.

52. Bodensteiner P, Binder M, Moncalvo JM, Agerer R, Hibbett DS. 2004. Phylogenetic relationships of cyphelloid homobasidiomycetes. Mol Phylogenet Evol 33:501-515 http://dx.doi.org/10.1016/j.ympev .2004 .06 .007 .

53. Schmitt I. 2011. Fruiting body evolution in the Ascomycota: a molecular perspective integrating lichenized and non-lichenized groups, p 187-204. In Pöggeler S, Wöstemeyer J (ed), The Mycota: Evolution of Fungi and Fungal-Like Organisms. Springer-Verlag, Berlin, Germany.

54. Kovacs GM, Trappe JM. 2014. Nomenclatural history and genealogies of desert truffles, p 21-37. In Kagan-Zur V, Roth-Bejerano N, Sitrit Y, Morte A (ed), Desert Truffles: Phylogeny, Physiology, Distribution and Domestication. Springer, Berlin Germany.

55. Kües U, Liu Y. 2000. Fruiting body production in Basidiomycetes. Appl Microbiol Biotechnol 54:141-152 http://dx.doi.org/10.1007 /s002530000396.

56. Kües U. 2000. Life history and developmental processes in the basidiomycete Coprinus cinereus. Microbiol Mol Biol Rev 64:316-353 http://dx.doi.org/10.1128/MMBR.64.2.316-353.2000.

57. Nagy LG, Házi J, Szappanos B, Kocsubé S, Bálint B, Rákhely G, Vágvölgyi C, Papp T. 2012. The evolution of defense mechanisms correlate with the explosive diversification of autodigesting Coprinellus mushrooms (Agaricales, Fungi). Syst Biol 61:595-607 http://dx.doi.org 110.1093/sysbio/sys002.

58. Clémencon H, Emmett V, Emmett EE (ed). 2004. Cytology and Plectology of Hymenomycetes. J Cramer, Berlin, Germany.

59. Singer R. 1986. The Agaricales in Modern Taxonomy, 4th ed. Koeltz Scientific Books, Koenigstein, Germany. 
60. Thiers HD. 1984. The secotioid syndrome. Mycologia 76:18 http://dx.doi.org/10.2307/3792830.

61. Bahn YS, Xue C, Idnurm A, Rutherford JC, Heitman J, Cardenas ME. 2007. Sensing the environment: lessons from fungi. Nat Rev Microbiol 5:57-69 http://dx.doi.org/10.1038/nrmicro1578.

62. Kamada T, Sano H, Nakazawa T, Nakahori K. 2010. Regulation of fruiting body photomorphogenesis in Coprinopsis cinerea. Fungal Genet Biol 47:917-921 http://dx.doi.org/10.1016/j.fgb.2010.05.003.

63. Bayram O, Krappmann S, Ni M, Bok JW, Helmstaedt K, Valerius O, Braus-Stromeyer S, Kwon NJ, Keller NP, Yu JH, Braus GH. 2008. VelB/ $\mathrm{VeA} /$ LaeA complex coordinates light signal with fungal development and secondary metabolism. Science 320:1504-1506 http://dx.doi.org/10.1126 Iscience.1155888.

64. Bayram O, Braus GH. 2012. Coordination of secondary metabolism and development in fungi: the velvet family of regulatory proteins. FEMS Microbiol Rev 36:1-24 http://dx.doi.org/10.1111/j.1574-6976.2011 $.00285 . x$.

65. Kück U, Beier AM, Teichert I. 2016. The composition and function of the striatin-interacting phosphatases and kinases (STRIPAK) complex in fungi. Fungal Genet Biol 90:31-38 http://dx.doi.org/10.1016/i.fgb 2015.10.001.

66. Frey S. 2015. The STRIPAK Complex and Its Role in FruitingBody Development of the Filamentous Fungus Sordaria macrospora. Georg-August University School of Science, Göttingen, Germany.

67. Ohm RA, de Jong JF, de Bekker C, Wösten HA, Lugones LG. 2011. Transcription factor genes of Schizophyllum commune involved in regulation of mushroom formation. Mol Microbiol 81:1433-1445 http://dx.doi.org/10.1111/j.1365-2958.2011.07776.x.

68. Ohm RA, de Jong JF, Lugones LG, Aerts A, Kothe E, Stajich JE, de Vries RP, Record E, Levasseur A, Baker SE, Bartholomew KA, Coutinho PM, Erdmann S, Fowler TJ, Gathman AC, Lombard V, Henrissat B, Knabe N, Kües U, Lilly WW, Lindquist E, Lucas S, Magnuson JK, Piumi F, Raudaskoski M, Salamov A, Schmutz J, Schwarze FW, vanKuyk PA, Horton JS, Grigoriev IV, Wösten HA. 2010. Genome sequence of the model mushroom Schizophyllum commune. Nat Biotechnol 28:957-963 http://dx.doi.org/10.1038/nbt.1643.

69. Masloff S, Pöggeler S, Kück U. 1999. The pro1(+) gene from Sordaria macrospora encodes a C6 zinc finger transcription factor required for fruiting body development. Genetics 152:191-199.

70. Traeger S, Altegoer F, Freitag M, Gabaldon T, Kempken F, Kumar A, Marcet-Houben M, Pöggeler S, Stajich JE, Nowrousian M. 2013. The genome and development-dependent transcriptomes of Pyronema confluens: a window into fungal evolution. PLoS Genet 9:e1003820 http://dx .doi.org/10.1371/journal.pgen.1003820.

71. Boulianne RP, Liu Y, Aebi M, Lu BC, Kües U. 2000. Fruiting body development in Coprinus cinereus: regulated expression of two galectins secreted by a non-classical pathway. Microbiology 146:18411853 http://dx.doi.org/10.1099/00221287-146-8-1841.

72. Iijima N, Yoshino H, Ten LC, Ando A, Watanabe K, Nagata Y. 2002. Two genes encoding fruit body lectins of Pleurotus cornucopiae: sequence similarity with the lectin of a nematode-trapping fungus. Biosci Biotechnol Biochem 66:2083-2089 http://dx.doi.org/10.1271/bbb.66.2083.

73. Wösten HAB. 2001. Hydrophobins: multipurpose proteins. Annu Rev Microbiol 55:625-646 http://dx.doi.org/10.1146/annurev.micro.55.1.625.

74. Floudas D, et al. 2012. The Paleozoic origin of enzymatic lignin decomposition reconstructed from 31 fungal genomes. Science 336:17151719 http://dx.doi.org/10.1126/science.1221748.

75. Nagy LG, Riley R, Tritt A, Adam C, Daum C, Floudas D, Sun H, Yadav JS, Pangilinan J, Larsson KH, Matsuura K, Barry K, Labutti K, Kuo R, Ohm RA, Bhattacharya SS, Shirouzu T, Yoshinaga Y, Martin FM, Grigoriev IV, Hibbett DS. 2016. Comparative genomics of early-diverging mushroom-forming fungi provides insights into the origins of lignocellulose decay capabilities. Mol Biol Evol 33:959-970 http://dx.doi.org /10.1093/molbev/msv337.
76. Riley R, Salamov AA, Brown DW, Nagy LG, Floudas D, Held BW, Levasseur A, Lombard V, Morin E, Otillar R, Lindquist EA, Sun H, LaButti KM, Schmutz J, Jabbour D, Luo H, Baker SE, Pisabarro AG, Walton JD, Blanchette RA, Henrissat B, Martin F, Cullen D, Hibbett DS, Grigoriev IV. 2014. Extensive sampling of basidiomycete genomes demonstrates inadequacy of the white-rot/brown-rot paradigm for wood decay fungi. Proc Natl Acad Sci USA 111:9923-9928 http://dx.doi.org /10.1073/pnas.1400592111.

77. Floudas D, Held BW, Riley R, Nagy LG, Koehler G, Ransdell AS, Younus H, Chow J, Chiniquy J, Lipzen A, Tritt A, Sun H, Haridas S, LaButti K, Ohm RA, Kües U, Blanchette RA, Grigoriev IV, Minto RE, Hibbett DS. 2015. Evolution of novel wood decay mechanisms in Agaricales revealed by the genome sequences of Fistulina hepatica and Cylindrobasidium torrendii. Fungal Genet Biol 76:78-92 http://dx.doi .org/10.1016/j.fgb.2015.02.002.

78. Martinez D, et al. 2009. Genome, transcriptome, and secretome analysis of wood decay fungus Postia placenta supports unique mechanisms of lignocellulose conversion. Proc Natl Acad Sci USA 106:19541959 http://dx.doi.org/10.1073/pnas.0809575106.

79. Martinez D, Larrondo LF, Putnam N, Gelpke MD, Huang K, Chapman J, Helfenbein KG, Ramaiya P, Detter JC, Larimer F, Coutinho PM, Henrissat B, Berka R, Cullen D, Rokhsar D. 2004. Genome sequence of the lignocellulose degrading fungus Phanerochaete chrysosporium strain RP78. Nat Biotechnol 22:695-700 http://dx.doi.org/10.1038/nbt967.

80. Berbee ML, Taylor JW. 2010. Dating the molecular clock in fungi: how close are we? Fungal Biol Rev 24:1-16 http://dx.doi.org/10.1016 /i.fbr.2010.03.001.

81. Beimforde C, Feldberg K, Nylinder S, Rikkinen J, Tuovila H, Dörfelt H, Gube M, Jackson DJ, Reitner J, Seyfullah LJ, Schmidt AR. 2014. Estimating the Phanerozoic history of the Ascomycota lineages: combining fossil and molecular data. Mol Phylogenet Evol 78:386-398 http://dx.doi.org/10.1016/j.ympev.2014.04.024.

82. Chang Y, Wang S, Sekimoto S, Aerts AL, Choi C, Clum A, LaButti KM, Lindquist EA, Yee Ngan C, Ohm RA, Salamov AA, Grigoriev IV, Spatafora JW, Berbee ML. 2015. Phylogenomic analyses indicate that early fungi evolved digesting cell walls of algal ancestors of land plants. Genome Biol Evol 7:1590-1601 http://dx.doi.org/10.1093/gbe/evv090.

83. Robinson JM. 1990. Lignin, land plants, and fungi: biological evolution affecting Phanerozoic oxygen balance. Geology 18:607-610 http://dx.doi.org/10.1130/0091-7613(1990)018<0607:LLPAFB>2.3 .CO;2.

84. Eastwood DC. 2014. Evolution of fungal wood decay, p 93-112. In Schultz TP, Goodell B, Nicholas DD (ed). Deterioration and Protection of Sustainable Biomaterials. ACS Symposium Series. American Chemical Society, Washington, DC.

85. Cragg SM, Beckham GT, Bruce NC, Bugg TD, Distel DL, Dupree P, Etxabe AG, Goodell BS, Jellison J, McGeehan JE, McQueen-Mason SJ, Schnorr K, Walton PH, Watts JE, Zimmer M. 2015. Lignocellulose degradation mechanisms across the tree of life. Curr Opin Chem Biol 29:108119 http://dx.doi.org/10.1016/j.cbpa.2015.10.018.

86. Hibbett DS, Donoghue MJ. 2001. Analysis of character correlations among wood decay mechanisms, mating systems, and substrate ranges in homobasidiomycetes. Syst Biol 50:215-242 http://dx.doi.org/10.1080 $\underline{10635150151125879}$.

87. Rytioja J, Hildén K, Yuzon J, Hatakka A, de Vries RP, Mäkelä MR. 2014. Plant-polysaccharide-degrading enzymes from Basidiomycetes. Microbiol Mol Biol Rev 78:614-649 http://dx.doi.org/10.1128/MMBR.00035-14. 88. Ruiz-Dueñas FJ, Lundell T, Floudas D, Nagy LG, Barrasa JM, Hibbett DS, Martínez AT. 2013. Lignin-degrading peroxidases in Polyporales: an evolutionary survey based on 10 sequenced genomes. Mycologia 105:1428-1444 http://dx.doi.org/10.3852/13-059.

89. Ruiz-Dueñas FJ, Martínez AT. 2009. Microbial degradation of lignin: how a bulky recalcitrant polymer is efficiently recycled in nature and how we can take advantage of this. Microb Biotechnol 2:164-177 http://dx .doi.org/10.1111/j.1751-7915.2008.00078.x. 
90. Vaaje-Kolstad G, Westereng B, Horn SJ, Liu Z, Zhai H, Sørlie M, Eijsink VG. 2010. An oxidative enzyme boosting the enzymatic conversion of recalcitrant polysaccharides. Science 330:219-222 http://dx.doi .org/10.1126/science.1192231.

91. Morgenstern I, Powlowski J, Tsang A. 2014. Fungal cellulose degradation by oxidative enzymes: from dysfunctional GH61 family to powerful lytic polysaccharide monooxygenase family. Brief Funct Genomics 13:471-481.

92. van den Brink J, de Vries RP. 2011. Fungal enzyme sets for plant polysaccharide degradation. Appl Microbiol Biotechnol 91:1477-1492 http://dx.doi.org/10.1007/s00253-011-3473-2.

93. Ruiz-Dueñas FJ, Fernández E, Martínez MJ, Martínez AT. 2011. Pleurotus ostreatus heme peroxidases: an in silico analysis from the genome sequence to the enzyme molecular structure. C R Biol 334:795-805 http://dx.doi.org/10.1016/j.crvi.2011.06.004.

94. Martinez AT, Speranza M, Ruiz-Duenas FJ, Ferreira P, Camarero S, Guillen F, et al. 2005. Biodegradation of lignocellulosics: microbial, chemical, and enzymatic aspects of the fungal attack of lignin. Int Microbiol 8:195-204.

95. Firn RD, Jones CG. 2003. Natural products: a simple model to explain chemical diversity. Nat Prod Rep 20:382-391 http://dx.doi.org/10.1039 /b208815k.

96. Li YF, Tsai KJ, Harvey CJ, Li JJ, Ary BE, Berlew EE, Boehman BL, Findley DM, Friant AG, Gardner CA, Gould MP, Ha JH, Lilley BK, McKinstry EL, Nawal S, Parry RC, Rothchild KW, Silbert SD, Tentilucci MD, Thurston AM, Wai RB, Yoon Y, Aiyar RS, Medema MH, Hillenmeyer ME, Charkoudian LK. 2016. Comprehensive curation and analysis of fungal biosynthetic gene clusters of published natural products. Fungal Genet Biol 89:18-28 http://dx.doi.org/10.1016/j.fgb.2016.01.012. 97. Lewis K. 2013. Platforms for antibiotic discovery. Nat Rev Drug Discov 12:371-387 http://dx.doi.org/10.1038/nrd3975.

98. Inglis DO, Binkley J, Skrzypek MS, Arnaud MB, Cerqueira GC, Shah P, Wymore F, Wortman JR, Sherlock G. 2013. Comprehensive annotation of secondary metabolite biosynthetic genes and gene clusters of Aspergillus nidulans, A. fumigatus, A. niger and A. oryzae. BMC Microbiol 13:91 http://dx.doi.org/10.1186/1471-2180-13-91.

99. Brakhage AA. 2013. Regulation of fungal secondary metabolism. Nat Rev Microbiol 11:21-32 http://dx.doi.org/10.1038/nrmicro2916.

100. Wolpert TJ, Dunkle LD, Ciuffetti LM. 2002. Host-selective toxins and avirulence determinants: what's in a name? Annu Rev Phytopathol 40:251-285 http://dx.doi.org/10.1146/annurev.phyto.40.011402.114210. 101. Brosch G, Ransom R, Lechner T, Walton JD, Loidl P. 1995. Inhibition of maize histone deacetylases by $\mathrm{HC}$ toxin, the host-selective toxin of Cochliobolus carbonum. Plant Cell 7:1941-1950 http://dx.doi.org /10.1105/tpc.7.11.1941.

102. Sharon A, Elad Y, Barakat R, Tudzynski P. 2007. Phytohormones in Botrytis-plant interactions, p 163-179. In Elad Y, Williamson B, Tudzynski P, Delen N (ed), Botrytis: Biology, Pathology and Control. Springer, Dordrecht, The Netherlands. http://dx.doi.org/10.1007/978-1 -4020-2626-3_10

103. Kosentka P, Sprague SL, Ryberg M, Gartz J, May AL, Campagna SR, Matheny PB. 2013. Evolution of the toxins muscarine and psilocybin in a family of mushroom-forming fungi. PLoS One 8:e64646 http://dx.doi .org/10.1371/journal.pone.0064646.

104. Rohlfs M, Albert M, Keller NP, Kempken F. 2007. Secondary chemicals protect mould from fungivory. Biol Lett 3:523-525 http://dx doi.org/10.1098/rsbl.2007.0338.

105. Rudgers JA, Clay K. 2007. Endophyte symbiosis with tall fescue: how strong are the impacts on communities and ecosystems? Fungal Biol Rev 21:107-124 http://dx.doi.org/10.1016/j.fbr.2007.05.002.

106. Soliman SS, Greenwood JS, Bombarely A, Mueller LA, Tsao R, Mosser DD, Raizada MN. 2015. An endophyte constructs fungicidecontaining extracellular barriers for its host plant. Curr Biol 25:25702576 http://dx.doi.org/10.1016/j.cub.2015.08.027.
107. Arnold AE, Mejía LC, Kyllo D, Rojas EI, Maynard Z, Robbins N, Herre EA. 2003. Fungal endophytes limit pathogen damage in a tropical tree. Proc Natl Acad Sci USA 100:15649-15654 http://dx.doi.org/10.1073 Ipnas.2533483100.

108. Hider RC, Kong X. 2010. Chemistry and biology of siderophores. Nat Prod Rep 27:637-657 http://dx.doi.org/10.1039/b906679a.

109. Hwang LH, Mayfield JA, Rine J, Sil A. 2008. Histoplasma requires SID1, a member of an iron-regulated siderophore gene cluster, for host colonization. PLoS Pathog 4:e1000044 http://dx.doi.org/10.1371/journal .ppat.1000044.

110. Mascuch SJ, Moree WJ, Hsu CC, Turner GG, Cheng TL, Blehert DS, Kilpatrick AM, Frick WF, Meehan MJ, Dorrestein PC, Gerwick L. 2015. Direct detection of fungal siderophores on bats with white-nose syndrome via fluorescence microscopy-guided ambient ionization mass spectrometry. PLoS One 10:e0119668 http://dx.doi.org/10.1371/journal .pone. 0119668 .

111. Eisenman HC, Casadevall A. 2012. Synthesis and assembly of fungal melanin. Appl Microbiol Biotechnol 93:931-940 http://dx.doi.org 110.1007/s00253-011-3777-2.

112. Smith ML, Bruhn JN, Anderson JB. 1992. The fungus Armillaria bulbosa is among the largest and oldest living organisms. Nature 356:428-431 http://dx.doi.org/10.1038/356428a0.

113. Nosanchuk JD, Casadevall A. 2003. The contribution of melanin to microbial pathogenesis. Cell Microbiol 5:203-223 http://dx.doi.org 110.1046/j.1462-5814.2003.00268.x.

114. Molnár K, Farkas E. 2010. Current results on biological activities of lichen secondary metabolites: a review. Z Naturforsch C 65:157-173 http://dx.doi.org/10.1515/znc-2010-3-401.

115. Hoffmeister D, Keller NP. 2007. Natural products of filamentous fungi: enzymes, genes, and their regulation. Nat Prod Rep 24:393-416 http://dx.doi.org/10.1039/B603084J.

116. Walton JD, Hallen-Adams HE, Luo H. 2010. Ribosomal biosynthesis of the cyclic peptide toxins of Amanita mushrooms. Biopolymers 94:659-664 http://dx.doi.org/10.1002/bip.21416.

117. Mitchell NJ, Bowers E, Hurburgh C, Wu F. 2016. Potential economic losses to the US corn industry from aflatoxin contamination. Food Addit Contam Part A Chem Anal Control Expo Risk Assess 33:540-550 http://dx.doi.org/10.1080/19440049.2016.1138545.

118. Endo A. 2010. A historical perspective on the discovery of statins. Proc Jpn Acad Ser B Phys Biol Sci 86:484-493 http://dx.doi.org/10.2183 Ipjab.86.484.

119. Woloshuk CP, Shim WB. 2013. Aflatoxins, fumonisins, and trichothecenes: a convergence of knowledge. FEMS Microbiol Rev 37:94109 http://dx.doi.org/10.1111/1574-6976.12009.

120. Gallois A, Gross B, Langlois D, Spinnler H-E, Brunerie P. 1990. Influence of culture conditions on production of flavour compounds by 29 ligninolytic Basidiomycetes. Mycol Res 94:494-504 http://dx.doi.org /10.1016/S0953-7562(10)80010-3.

121. Panaccione DG, Beaulieu WT, Cook D. 2014. Bioactive alkaloids in vertically transmitted fungal endophytes. Funct Ecol 28:299-314 http://dx.doi.org/10.1111/1365-2435.12076.

122. Araújo AM, Carvalho F, Bastos ML, Guedes de Pinho P, Carvalho M. 2015. The hallucinogenic world of tryptamines: an updated review. Arch Toxicol 89:1151-1173 http://dx.doi.org/10.1007/s00204-015-1513-x.

123. Bidartondo MI, Read DJ, Trappe JM, Merckx V, Ligrone R, Duckett JG. 2011. The dawn of symbiosis between plants and fungi. Biol Lett 7:574-577 http://dx.doi.org/10.1098/rsbl.2010.1203.

124. Keller NP, Hohn TM. 1997. Metabolic pathway gene clusters in filamentous fungi. Fungal Genet Biol 21:17-29 http://dx.doi.org/10.1006 Ifgbi.1997.0970.

125. Gluck-Thaler E, Slot JC. 2015. Dimensions of horizontal gene transfer in eukaryotic microbial pathogens. PLoS Pathog 11:e1005156 http://dx.doi.org/10.1371/journal.ppat.1005156. 
126. Campbell MA, Rokas A, Slot JC. 2012. Horizontal transfer and death of a fungal secondary metabolic gene cluster. Genome Biol Evol 4:289-293 http://dx.doi.org/10.1093/gbe/evs011.

127. Marcet-Houben M, Gabaldón T. 2016. Horizontal acquisition of toxic alkaloid synthesis in a clade of plant associated fungi. Fungal Genet Biol 86:71-80 http://dx.doi.org/10.1016/j.fgb.2015.12.006.

128. Slot JC, Rokas A. 2011. Horizontal transfer of a large and highly toxic secondary metabolic gene cluster between fungi. Curr Biol 21:134$139 \mathrm{http}: / / \mathrm{dx}$. doi.org/10.1016/j.cub.2010.12.020.

129. Bradshaw RE, Slot JC, Moore GG, Chettri P, de Wit PJ, Ehrlich KC, Ganley AR, Olson MA, Rokas A, Carbone I, Cox MP. 2013. Fragmentation of an aflatoxin-like gene cluster in a forest pathogen. New Phytol 198:525-535 http://dx.doi.org/10.1111/nph.12161.

130. Heckman DS, Geiser DM, Eidell BR, Stauffer RL, Kardos NL, Hedges SB. 2001. Molecular evidence for the early colonization of land by fungi and plants. Science 293:1129-1133 http://dx.doi.org/10.1126 /science.1061457.

131. Frank B. 1885. Über die auf Wurzelsymbiose beruhende Ernährung gewisser Bäume durch unterirdische Pilze. Ber Dtsch Bot Ges 3:128-145. 132. Trappe JMAB. 2005. A.B. Frank and mycorrhizae: the challenge to evolutionary and ecologic theory. Mycorrhiza 15:277-281 http://dx.doi .org/10.1007/s00572-004-0330-5.

133. Smith SE, Read DJ. 2008. Mycorrhizal Symbiosis. Academic Press: San Diego, CA.

134. Brundrett MC. 2002. Coevolution of roots and mycorrhizas of land plants. New Phytol 154:275-304 http://dx.doi.org/10.1046/j.1469-8137 2002.00397.x.

135. Brundrett MC. 2009. Mycorrhizal associations and other means of nutrition of vascular plants: understanding the global diversity of host plants by resolving conflicting information and developing reliable means of diagnosis. Plant Soil 320:37-77 http://dx.doi.org/10.1007/s11104-008 -9877-9.

136. Wang B, Qiu YL. 2006. Phylogenetic distribution and evolution of mycorrhizas in land plants. Mycorrhiza 16:299-363 http://dx.doi.org /10.1007/s00572-005-0033-6.

137. Tedersoo L, May TW, Smith ME. 2010. Ectomycorrhizal lifestyle in fungi: global diversity, distribution, and evolution of phylogenetic lineages. Mycorrhiza 20:217-263 http://dx.doi.org/10.1007/s00572-009 $\underline{-0274-x}$.

138. van der Heijden MG, Martin FM, Selosse MA, Sanders IR. 2015. Mycorrhizal ecology and evolution: the past, the present, and the future. New Phytol 205:1406-1423 http://dx.doi.org/10.1111/nph.13288.

139. Read DJ, Perez-Moreno J. 2003. Mycorrhizas and nutrient cycling in ecosystems: a journey towards relevance? New Phytol 157:475-492 http://dx.doi.org/10.1046/j.1469-8137.2003.00704.x.

140. Vohník M, Sadowsky JJ, Kohout P, Lhotáková Z, Nestby R, Kolařík M. 2012. Novel root-fungus symbiosis in Ericaceae: sheathed ericoid mycorrhiza formed by a hitherto undescribed basidiomycete with affinities to Trechisporales. PLoS One 7:e39524 http://dx.doi.org/10.1371/journal .pone.0039524.

141. Peterson RL, Massicotte HB, Melville LH. 2004. Mycorrhizas: Anatomy and Cell Biology. National Research Council of Canada, Ottawa, Canada.

142. Cameron DD, Leake JR, Read DJ. 2006. Mutualistic mycorrhiza in orchids: evidence from plant-fungus carbon and nitrogen transfers in the green-leaved terrestrial orchid Goodyera repens. New Phytol 171:405416 http://dx.doi.org/10.1111/j.1469-8137.2006.01767.x.

143. Kottke I, et al. 2010. Atractiellomycetes belonging to the 'rust' lineage (Pucciniomycotina) form mycorrhizae with terrestrial and epiphytic neotropical orchids. Proc Biol Sci 277:1289-1298.

144. Fitter AH, Moyersoen B. 1996. Evolutionary trends in root-microbe symbioses. Philos Trans R Soc Lond, B 351:1367-1375 http://dx.doi.org /10.1098/rstb.1996.0120.
145. Brachmann A, Parniske M. 2006. The most widespread symbiosis on Earth. PLoS Biol 4:e239 http://dx.doi.org/10.1371/journal.pbio .0040239 .

146. Pagano MC, Oehl F, Silva GA, Maia LC, Silva DK, Cabello MN. 2016. Advances in arbuscular mycorrhizal taxonomy, p 15-21. In Pagano M (ed), Recent Advances on Mycorrhizal Fungi. Springer, Cham, Switzerland. http://dx.doi.org/10.1007/978-3-319-24355-9_2

147. Tisserant E, Malbreil M, Kuo A, Kohler A, Symeonidi A, Balestrini R, Charron P, Duensing N, Frei dit Frey N, Gianinazzi-Pearson V, Gilbert LB, Handa Y, Herr JR, Hijri M, Koul R, Kawaguchi M, Krajinski F, Lammers PJ, Masclaux FG, Murat C, Morin E, Ndikumana S, Pagni M, Petitpierre D, Requena N, Rosikiewicz P, Riley R, Saito K, San Clemente $H$, Shapiro H, van Tuinen D, Bécard G, Bonfante P, Paszkowski U, Shachar-Hill YY, Tuskan GA, Young JP, Sanders IR, Henrissat B, Rensing SA, Grigoriev IV, Corradi N, Roux C, Martin F. 2013. Genome of an arbuscular mycorrhizal fungus provides insight into the oldest plant symbiosis. Proc Natl Acad Sci USA 110:20117-20122 http://dx.doi.org /10.1073/pnas.1313452110.

148. Ropars J, Toro KS, Noel J, Pelin A, Charron P, Farinelli L, Marton T, Krüger M, Fuchs J, Brachmann A, Corradi N. 2016. Evidence for the sexual origin of heterokaryosis in arbuscular mycorrhizal fungi. Nat Microbiol 1:16033 http://dx.doi.org/10.1038/nmicrobiol.2016.33.

149. Bonfante P, Genre A. 2015. Arbuscular mycorrhizal dialogues: do you speak 'plantish' or 'fungish'? Trends Plant Sci 20:150-154 http://dx .doi.org/10.1016/j.tplants.2014.12.002.

150. Parniske M. 2000. Intracellular accommodation of microbes by plants: a common developmental program for symbiosis and disease? Curr Opin Plant Biol 3:320-328 http://dx.doi.org/10.1016/S1369-5266 (00)00088-1.

151. Huisman R, Bouwmeester K, Brattinga M, Govers F, Bisseling T, Limpens E. 2015. Haustorium formation in Medicago truncatula roots infected by Phytophthora palmivora does not involve the common endosymbiotic program shared by arbuscular mycorrhizal fungi and rhizobia. Mol Plant Microbe Interact 28:1271-1280 http://dx.doi.org /10.1094/MPMI-06-15-0130-R.

152. Stubblefield SP, Taylor TN, Trappe JM. 1987. Fossil mycorrhizae: a case for symbiosis. Science 237:59-60 http://dx.doi.org/10.1126/science .237 .4810 .59 .

153. Remy W, Taylor TN, Hass H, Kerp H. 1994. Four hundred-millionyear-old vesicular arbuscular mycorrhizae. Proc Natl Acad Sci USA 91: 11841-11843 http://dx.doi.org/10.1073/pnas.91.25.11841.

154. Redecker D, Kodner R, Graham LE. 2000. Glomalean fungi from the Ordovician. Science 289:1920-1921 http://dx.doi.org/10.1126/science .289 .5486 .1920 .

155. Duckett JG, Carafa A, Ligrone R. 2006. A highly differentiated glomeromycotean association with the mucilage-secreting, primitive antipodean liverwort Treubia (Treubiaceae): clues to the origins of mycorrhizas. Am J Bot 93:797-813 http://dx.doi.org/10.3732/ajb.93 .6 .797 .

156. Russell J, Bulman S. 2005. The liverwort Marchantia foliacea forms a specialized symbiosis with arbuscular mycorrhizal fungi in the genus Glomus. New Phytol 165:567-579 http://dx.doi.org/10.1111/j.1469 -8137.2004.01251.x.

157. Krings M, Taylor TN, Hass H, Kerp H, Dotzler N, Hermsen EJ. 2007. Fungal endophytes in a 400-million-yr-old land plant: infection pathways, spatial distribution, and host responses. New Phytol 174:648657 http://dx.doi.org/10.1111/j.1469-8137.2007.02008.x.

158. Ligrone R, Carafa A, Lumini E, Bianciotto V, Bonfante P, Duckett JG. 2007. Glomeromycotean associations in liverworts: a molecular, cellular, and taxonomic analysis. Am J Bot 94:1756-1777 http://dx.doi.org /10.3732/ajb.94.11.1756.

159. Pirozynski KA, Malloch DW. 1975. The origin of land plants: a matter of mycotrophism. Biosystems 6:153-164 http://dx.doi.org /10.1016/0303-2647(75)90023-4. 
Nagy et al.

160. Spatafora JW, Chang Y, Benny GL, Lazarus K, Smith ME, Berbee ML, Bonito G, Corradi N, Grigoriev I, Gryganskyi A, James TY, O'Donnell K, Roberson RW, Taylor TN, Uehling J, Vilgalys R, White MM, Stajich JE. 2016. A phylum-level phylogenetic classification of zygomycete fungi based on genome-scale data. Mycologia 108:10281046 http://dx.doi.org/10.3852/16-042.

161. Redecker D, Raab P. 2006. Phylogeny of the glomeromycota (arbuscular mycorrhizal fungi): recent developments and new gene markers. Mycologia 98:885-895 http://dx.doi.org/10.1080/15572536 .2006.11832618.

162. Lee J, Young JP. 2009. The mitochondrial genome sequence of the arbuscular mycorrhizal fungus Glomus intraradices isolate 494 and implications for the phylogenetic placement of Glomus. New Phytol 183:200-211 http://dx.doi.org/10.1111/j.1469-8137.2009.02834.x.

163. Lin K, Limpens E, Zhang Z, Ivanov S, Saunders DG, Mu D, Pang E, Cao H, Cha H, Lin T, Zhou Q, Shang Y, Li Y, Sharma T, van Velzen R, de Ruijter N, Aanen DK, Win J, Kamoun S, Bisseling T, Geurts R, Huang S. 2014. Single nucleus genome sequencing reveals high similarity among nuclei of an endomycorrhizal fungus. PLoS Genet 10:e1004078 http://dx doi.org/10.1371/journal.pgen.1004078.

164. Desiro A, Duckett JG, Pressel S, Villarreal JC, Bidartondo MI. 2013. Fungal symbioses in hornworts: a chequered history. Proc Biol Sci 280:20130207.

165. Field KJ, Rimington WR, Bidartondo MI, Allinson KE, Beerling DJ, Cameron DD, Duckett JG, Leake JR, Pressel S. 2015. First evidence of mutualism between ancient plant lineages (Haplomitriopsida liverworts) and Mucoromycotina fungi and its response to simulated Palaeozoic changes in atmospheric CO2. New Phytol 205:743-756 http://dx.doi.org 10.1111/nph.13024.

166. Field KJ, Rimington WR, Bidartondo MI, Allinson KE, Beerling DJ, Cameron DD, Duckett JG, Leake JR, Pressel S. 2016. Functional analysis of liverworts in dual symbiosis with Glomeromycota and Mucoromycotina fungi under a simulated Palaeozoic CO2 decline. ISME J 10:1514-1526 http://dx.doi.org/10.1038/ismej.2015.204.

167. Strullu-Derrien C, Kenrick P, Pressel S, Duckett JG, Rioult JP, Strullu DG. 2014. Fungal associations in Horneophyton ligneri from the Rhynie chert (c. 407 million year old) closely resemble those in extant lower land plants: novel insights into ancestral plant-fungus symbioses. New Phytol 203:964-979 http://dx.doi.org/10.1111/nph.12805.

168. Bravo A, York T, Pumplin N, Mueller LA, Harrison MJ. 2016. Genes conserved for arbuscular mycorrhizal symbiosis identified through phylogenomics. Nat Plants 2:15208 http://dx.doi.org/10.1038/nplants .2015 .208

169. Martin F, Kohler A, Murat C, Veneault-Fourrey C, Hibbett DS. 2016. Unearthing the roots of ectomycorrhizal symbioses. Nat Rev Microbiol 14:760-773 http://dx.doi.org/10.1038/nrmicro.2016.149.

170. Kottke I, Kovács GM. 2013. Mycorrhizae-rhizosphere determinants of plant communities: what can we learn from the tropics? p 40-1-40-13. In Eshel A, Beeckman T (ed), Plant Roots: The Hidden Half, 4th ed. CRC Press, Boca Raton, FL.

171. Kottke I, Oberwinkler F. 1987. The cellular structure of the Hartig net: coenocytic and transfer cell-like organization. Nord J Bot 7:85-95 http://dx.doi.org/10.1111/j.1756-1051.1987.tb00919.x.

172. Agerer R. 2001. Exploration types of ectomycorrhizae. Mycorrhiza 11:107-114 http://dx.doi.org/10.1007/s005720100108.

173. Kohler A, et al, Mycorrhizal Genomics Initiative Consortium. 2015. Convergent losses of decay mechanisms and rapid turnover of symbiosis genes in mycorrhizal mutualists. Nat Genet 47:410-415 http://dx.doi.org /10.1038/ng.3223.

174. Martin F, et al. 2010. Périgord black truffle genome uncovers evolutionary origins and mechanisms of symbiosis. Nature 464:1033-1038 http://dx.doi.org/10.1038/nature08867.

175. Plett JM, Martin F. 2011. Blurred boundaries: lifestyle lessons from ectomycorrhizal fungal genomes. Trends Genet 27:14-22 http://dx.doi .org/10.1016/j.tig.2010.10.005.

176. Kuo A, Kohler A, Martin FM, Grigoriev IV. 2014. Expanding genomics of mycorrhizal symbiosis. Front Microbiol 5:582 http://dx.doi .org/10.3389/fmicb.2014.00582.

177. Plett JM, Daguerre Y, Wittulsky S, Vayssières A, Deveau A, Melton SJ, Kohler A, Morrell-Falvey JL, Brun A, Veneault-Fourrey C, Martin F. 2014. Effector MiSSP7 of the mutualistic fungus Laccaria bicolor stabilizes the Populus JAZ6 protein and represses jasmonic acid (JA) responsive genes. Proc Natl Acad Sci USA 111:8299-8304 http://dx .doi.org/10.1073/pnas.1322671111.

178. Plett JM, Martin F. 2015. Reconsidering mutualistic plant-fungal interactions through the lens of effector biology. Curr Opin Plant Biol 26:45-50 http://dx.doi.org/10.1016/j.pbi.2015.06.001.

179. Trappe JM. 1996. What is a mycorrhiza?, p 3-6. In Mycorrhizas in Integrated Systems from Genes to Plant Development. Proceedings of the 4th European Symposium on Mycorrhizas. European Commission, Directorate-General XII, Science, Research and Development, Brussels, Belgium. 